\title{
ARCHEOLOGICKÝ VÝZKUM HŘBITOVA KOLEM FARNÍHO KOSTELA SVATÉHO VAVŘINCE VE VYSOKÉM MÝTĚ
}

\author{
DAVID VÍCH - JANA ŠÍNOVÁ - TOMÁŠ BEK
}

\begin{abstract}
Abstrakt: V letech 2016-2017 probihal ve Vysokém Mýtě (Pardubický kraj, Česká republika) záchranný archeologický výzkum vyvolaný rekonstrukcí náměstí kolem kostela sv. Vavřince. Tento prosto byl využíván jako hřbitov od založeni města do doby kolem poloviny 16. století (přemístění hřbitova mimo areál hradeb). Vedle ziskáni některých poznatků o způsobu pohřbívání v zásadě nevybočujicím z dobového rámce se nám podařilo učinit si konkrétnějši predstavu o rozsahu hřbitova. Provedená antropologická analýza přináši první zjištěni o vrcholně středověkém až časně novověkém obyvatelstvu pochovaném kolem kostela včetně dokladu velmi pravděpodobné přitomnosti syfilitického onemocnění.
\end{abstract}

Klíčová slova: hřbitov - kostel - časný novověk - vrcholný středověk-antropologie - syfilis.

\section{Archaeological research into the churchyard by the parish Church of St. Lawrence, Vysoké Mýto}

Abstract: Rescue archaeological research was conducted in Vysoké Mýto (Pardubice Region, Czech Republic) in 2016-2017, in connection with the reconstruction of the town square around the Church of St. Lawrence. The area had been used as a churchyard from the time when the town was established until ca the mid-16th century (when the cemetery was transferred outside the town walls). Apart from findings about the manners of burial more or less corresponding to the period customs, the research gave a more precise idea about the size of the churchyard, while an anthropological analysis brought the first information about the high-medieval-early modern age inhabitants of the town buried in the vicinity of the church, including evidence of a highly probable occurrence of syphilis.

Key words: churchyard - church-early modern age - high Middle Ages - anthropology-syphilis.

\section{1 Úvod}

Město Vysoké Mýto bylo založeno na vyvýšeném místě nad nivou řeky Loučné v místě soutoku s Blahovským potokem (původně nazývaným „Naisbach“, Jireček 1886-1900, 37), a to, soudě zejména podle pravidelného půdorysného uspořádání, na zeleném drnu. První písemná zmínka o městě Vysoké Mýto pochází z roku 1265, kdy v zakládacím privilegiu je Poličce uděleno soudní právo podle vzoru Vysokého Mýta (CDB V/1, 673-376 č. 475). Zakládací listinu Vysokého Mýta neznáme, město vzniklo někdy nedlouho před tímto datem, ovšem podle všeho nikoliv dříve než v roce 1258/1259 (Kuča 2011, 466, 471). Někdy před rokem 1278 vydal Přemysl Otakar II. listinu, v níž nařizuje měštanům Vysokého Mýta, aby město opevnili. Za to je na dva roky osvobozuje od daní a na tři roky od placení cla (CIM II, 88-89 č. 27).

Na počátku 14. století se Vysoké Mýto stalo spolu s dalšími městy věnným městem českých královen. Listinou ze 17. srpna 1308 Eliška Rejčka potvrzuje věnným městům výsady (RBM II, 945 č. 2174). To odráží stav, k němuž podle Zbraslavské kroniky mělo dojít rok předtím (Zbraslavská kronika 1975, 152), ač k tomu konkrétní listinný doklad nemáme.'

\section{Kostel sv. Vavřince se hřbitovem}

Kostel sv. Vavřince se nachází uprostřed dnešního Vaňorného náměstí (obr. 1:1). Západní stranu tohoto prostoru uzavírá budova gymnázia, novostavba postavená mezi lety 1880-1882 (Hnát 1934, 139). Z jižní strany vymezuje náměstí tzv. černá škola, novogotická stavba, v jejíž nově postavené budově sídlila od roku 1857 městská trojtřídní nižší reálka (Hnát 1934, 136; dnes první stupeň ZŠ Javornického). Jihovýchodní prostor zaujímá zvonice (obr. 1:3) postavená v letech 1583-1585 v areálu již zrušeného hřbitova (Sommer 1977, 121) pro zavěšení zvonů, jejichž

1 Někdy je za počátek věnných měst označován již rok 1305 (Krsková 2001, 15). Problematika vzniku věnných měst byla podrobně osvětlena jinde (Frolík-Musil 2016, 244). 


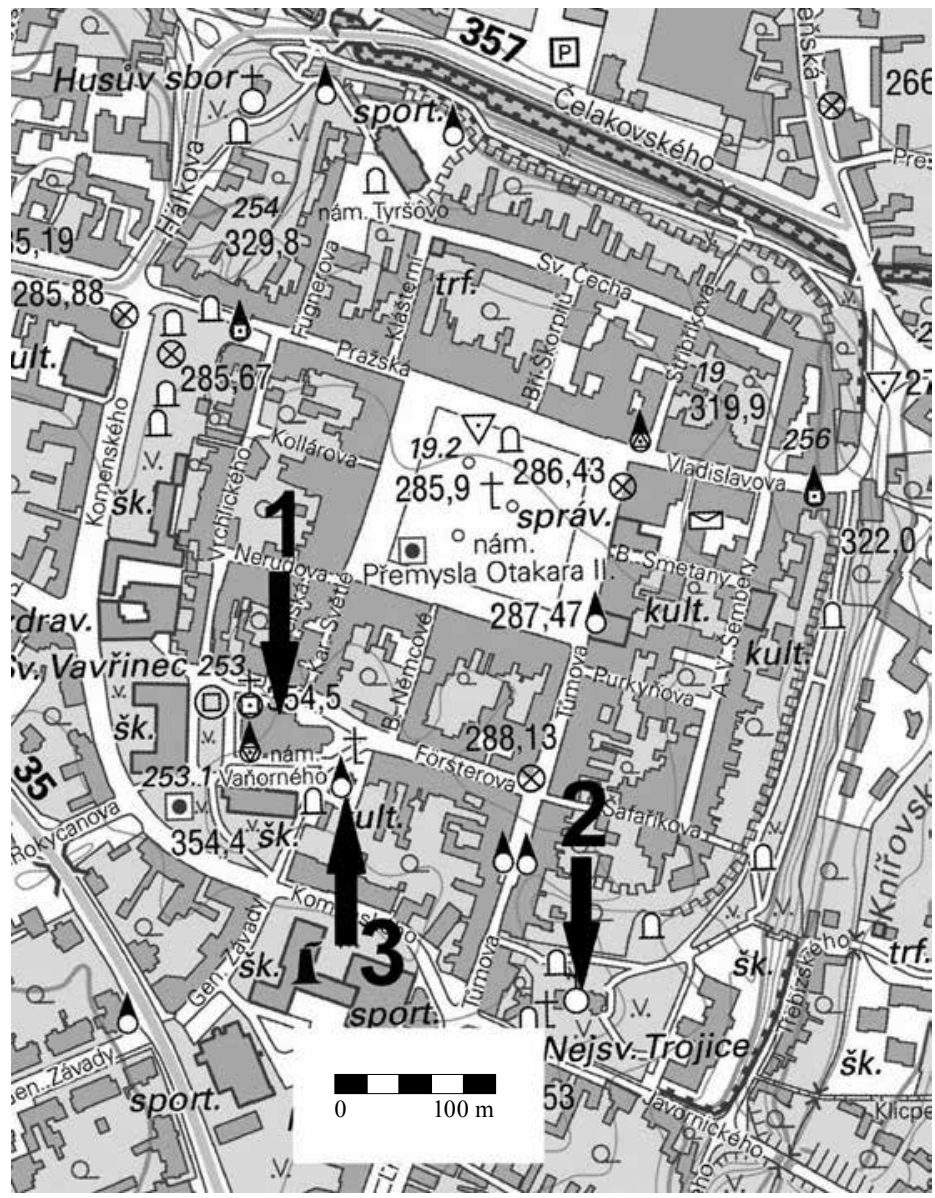

Obr. 1. Historické centrum Vysokého Mýta s vyznačenými polohami kostelů a zvonice. 1 - kostel sv. Vavřince; 2 - kostel Nejsvětějš́i Trojice; 3 - zvonice u kostela sv. Vavřince. Abb. 1. Historisches Zentrum von Vysoké Mýto mit Kennzeichnung der Lage der Kirchen und dem Glockenturm. 1 - St. Laurentius-Kirche; 2 - HI. Dreifaltigkeitskirche; 3 - Glockenturm bei der St. Laurentius-Kirche.

hmotnost zhoršovala statické problémy věží kostela sv. Vavřince (Kaplanová-Vácha 2001, 5354). Podle tradice měla být zvonice postavena $\mathrm{z}$ ruin kláštera zbořeného za husitských válek, podle jiného názoru budovatelé využili pískovcové kvádry a architektonické články z kostela sv. Vavřince zničeného požárem roku 1461 (Votrubec 1897), každopádně zdivo zvonice obsahuje zazděné gotické architektonické články.

Dle organického zapojení kostela a navazujícího prostoru do půdorysu středověkého města $\mathrm{v}$ jeho jihozápadní části v bezprostřední blízkosti městské hradby (obr. 14) se důvodně předpokládá vznik farního chrámu již v době založení města, přičemž za nejstarší části stojící stavby jsou dle různých stavebních detailů označovány jižní věž s přiléhajícím zdivem jižní lodi (Kaplanová-Vácha 2001,2-5). Na podobě chrámu získané v několika stavebních fázích ve druhé polovině 14. století se značně podepsaly požáry z let 1461 (Staré letopisy české 1980, 188), kolem roku 1517 a z 6 . srpna 1774 s následnými rekonstrukcemi, přičemž především koncem 15. a v první polovině 16 . století máme doloženy různé opravy, úpravy a přístavby (přístavba severní předsíně sklenuté obkročnou klenbou, kaple sv. Jana Křtitele; Wirth 1902, 108-113; 
Kaplanová-Vácha 2001, 9-18, 23) svědčící o čilém stavebním ruchu v této době. Větší změny přinesla regotizace kostela v letech 1875-1904, což se týká především západního průčelí (Votrubec 1892, 6-12). Je ovšem nutno poznamenat, že tato regotizace stavbu v podstatě zachránila, protože stav kostela byl v průběhu 19. století již dosti neutěšený (Kaplanová-Vácha 2001, 41). ${ }^{2}$ Vrcholně gotická podoba zůstala kostelu v zásadě podnes.

Prostor kolem kostela byl od jeho počátků využíván jako hřbitov. Kolem poloviny 16. století byl hřbitov zrušen a přesunut (Jireček 1884, 62) do okolí nového hřbitovního kostela Nejsvětější Trojice založeného v roce 1543 před hradbami města (obr. 1:2) na někdejší kněžské zahradě, v dnešních Jungmannových sadech (Šembera 1845, 43; Wirth 1902, 141-142). Tento hřbitov pak sloužil jako městský až do svého zrušení v roce 1906 (Hnát 1934, 144).

Archeologické výzkumy středověkých situací se dosud intravilánu Vysokého Mýta dotkly velmi skrovně, terénní zásahy (pokud vůbec byly nahlášeny a mohl proběhnout archeologický výzkum) umožňovaly většinou jenom dokumentaci řezů. V době před obsazením místa archeologa v Regionálním muzeu ve Vysokém Mýtě šlo dokonce většinou pouze o sběr movitých nálezů z výhozů. Světlou výjimku představuje výzkum z roku 1972 na staveništi nové pošty, který byl již souhrnně publikován (Sommer 1981; Šmejda 1999), i zde ovšem došlo k archeologickému výzkumu až po vybagrování stavební jámy (Sommer 1981, 315). ${ }^{3}$ Podobně jsme na tom i v př́ípadě okolí kostela sv. Vavřince, kde v 70. letech 20. století provedl výzkum P. Sommer při hloubení geologických sond. Prokázal zde tři vrstvy pohřbů středověkého hřbitova a kulturní vrstvu nasedající na sterilní podloží datovanou sporadickými nálezy keramiky do dob počátků města (Sommer 1977). V roce 1992 neohlášený výkop vodovodního řadu severně od kostela narušil archeologické situace, mohla však být opět pouze posbírána keramika z povrchu vykopané zeminy (Vích-Vokolek 1997, 25).

\section{Výzkum v roce 2016}

Na konci srpna 2016, asi dva dny před plánovaným zahájením výkopových prací, bylo archeologům Regionálního muzea ve Vysokém Mýtě oznámeno provádění výkopů pro přeložku plynovodního potrubí. Akce (předcházející prripravované rekonstrukci Vaňorného náměstí) měla mít podobu liniového výkopu o šířce $0,8 \mathrm{~m}$ situovaného severně od kostela sv. Vavřince např́ič původním středověkým hřbitovem. S ohledem na míru narušení archeologických terénů a nákladů s tím spojených se nakonec v rámci zainteresovaných institucí podařilo domluvit kompromis - tato stavba byla řešena protlakem, takže se výzkum omezil pouze na startovací jámy označené jako sondy 1-3/2016 (obr. 2).

Po ukončení této etapy výzkumu došlo k jednání s investorem plánované rekonstrukce Vaňorného náměstí, městem Vysoké Mýto a domluvě o předstihovém výzkumu v prostoru plánované kanalizační šachty, který byl pak realizován v říjnu a listopadu téhož roku (sonda 4/2016, obr. 2). Následovalo vyhloubení sond (ca $0,6 \times 0,6 \mathrm{~m}$ ) na vybraných místech s pomocí těžké stavební techniky za účelem zjištění hloubky uložení svrchní úrovně hrobů, do kterých však již dál nebylo zasahováno (sondy 5-8/2016, obr. 2). Získané údaje posloužily pro úpravu projektu tak, aby se minimalizovalo narušení archeologických situací při vlastní rekonstrukci náměstí, což vedle intaktních terénů následně šetřilo i čas a finanční prostředky investora. ${ }^{4}$

Celý výzkum začal hloubením rýhy pro výměnu plynovodního potrubí z ulice Karolíny Světlé propojující dnešní Vaňorného náměstí s ústředním náměstím Přemysla Otakara II. Hloubení výkopu za účasti archeologa přerušil objev hrobu H1/2016 (obr. 3). Hranice hřbitova nebyla při výkopu registrována. Po objevu prvního hrobu, jehož odkrytá část byla vzápětí standardně

\footnotetext{
2 Zajímavou zprávu při této př́ležitosti uvádí H. Jireček k roku 1889. Při bourání triumfálního oblouku byl v maltě mezi kameny nalezen parvus Jana Lucemburského (Jireček 1886-1900, 76).

3 Plošný výzkum, který realizovala M. Cejpová při př́istavbě muzea v zadním traktu domu čp. 127 v Šemberově ulici v roce 2007 , se bohužel zatím nedočkal zpracování ani do podoby nálezové zprávy.

4 Považujeme za nutné zde ocenit součinnost s investorem akce městem Vysoké Mýto.
} 


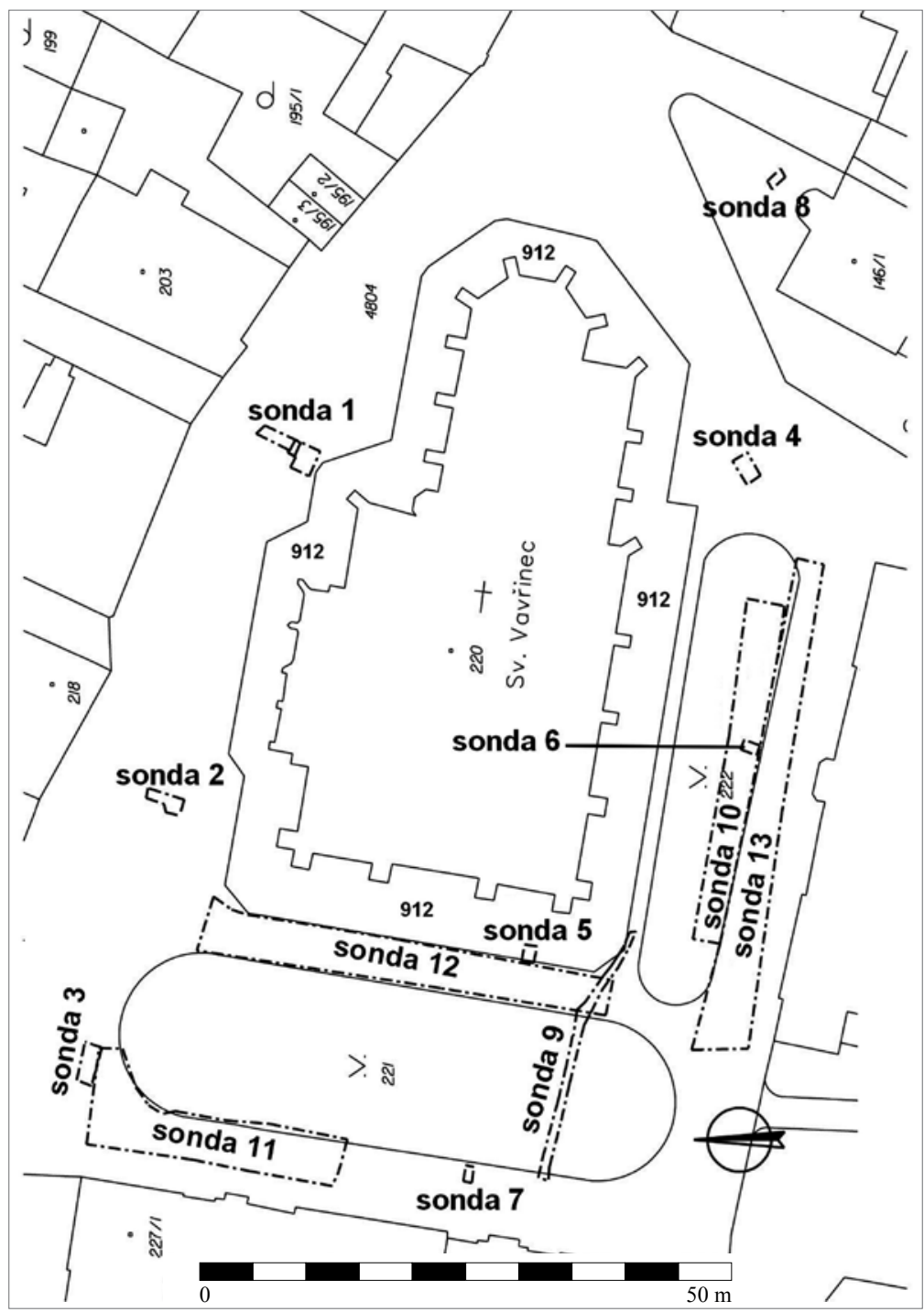

Obr. 2. Vysoké Mýto - Vaňorného náměstí s rozmístěním sond.

Abb. 2. Vysoké Mýto - Vaňorný-Platz mit Sondierschnittverteilung.

zdokumentována, byl výkop dokončen až $\mathrm{k}$ sondě 1 při zvednutí nivelety dna výkopu o několik centimetrů tak, že v rámci tohoto výkopu již nedošlo k narušování dalších hrobů.

Následovalo hloubení již zmíněných sond 1-3/2016 pro protlak plynovodního potrubí pomocí bagru za účasti archeologa. Sonda 2 zasáhla výhradně zničený terén do té míry, že ani řezy neposkytly žádné relevantní informace o prŕípadných archeologických situacích. Sonda 3 situovaná do blízkosti gymnázia (obr. 2) se již prokazatelně nacházela mimo prostor hřbitova. Výkop zde prot’al tmavou hlinitou vrstvu, na základně četných pozorování v intravilánu i extravilánu města spolehlivě interpretovanou jako přirozený půdní horizont, který nasedal na sterilní podloží. 


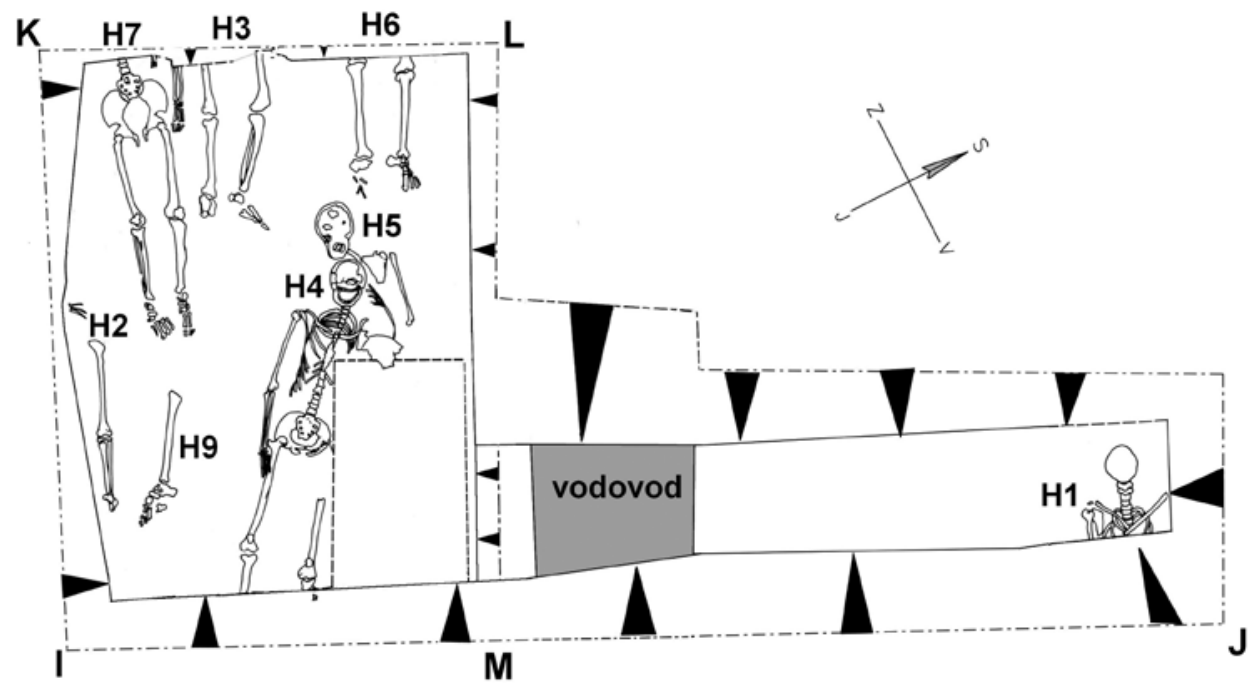

Obr. 3. Vysoké Mýto - Vaňorného náměstí. Sonda 1, svrchní úroveň hrobů.

Abb. 3. Vysoké Mýto - Vaňorný-Platz. Sondierschnitt 1, oberes Gräberniveau.

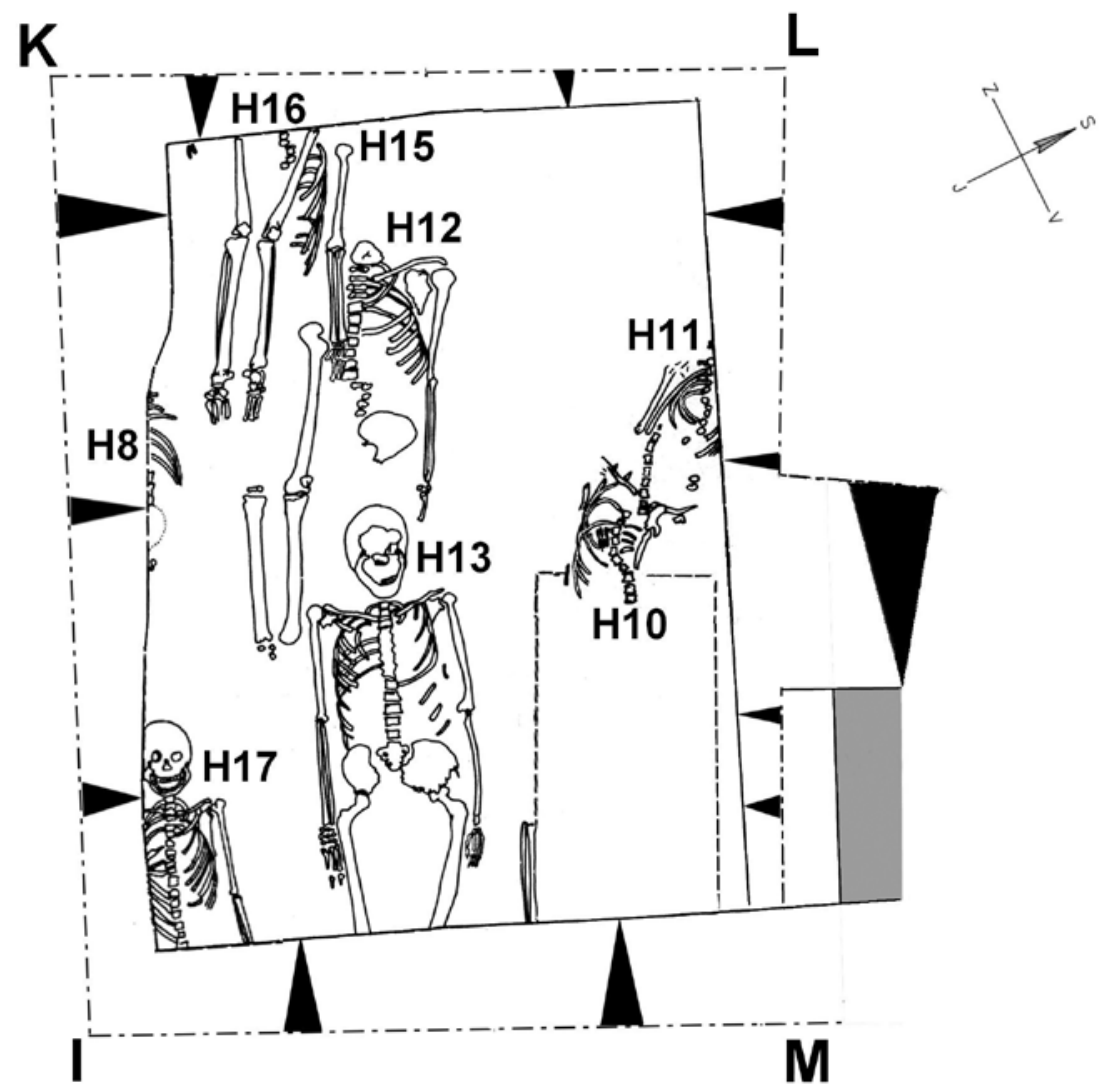

Obr. 4. Vysoké Mýto - Vaňorného náměstí. Sonda 1, střední úroveň hrobů.

Abb. 4. Vysoké Mýto - Vaňorný-Platz. Sondierschnitt 1, mittleres Gräberniveau. 


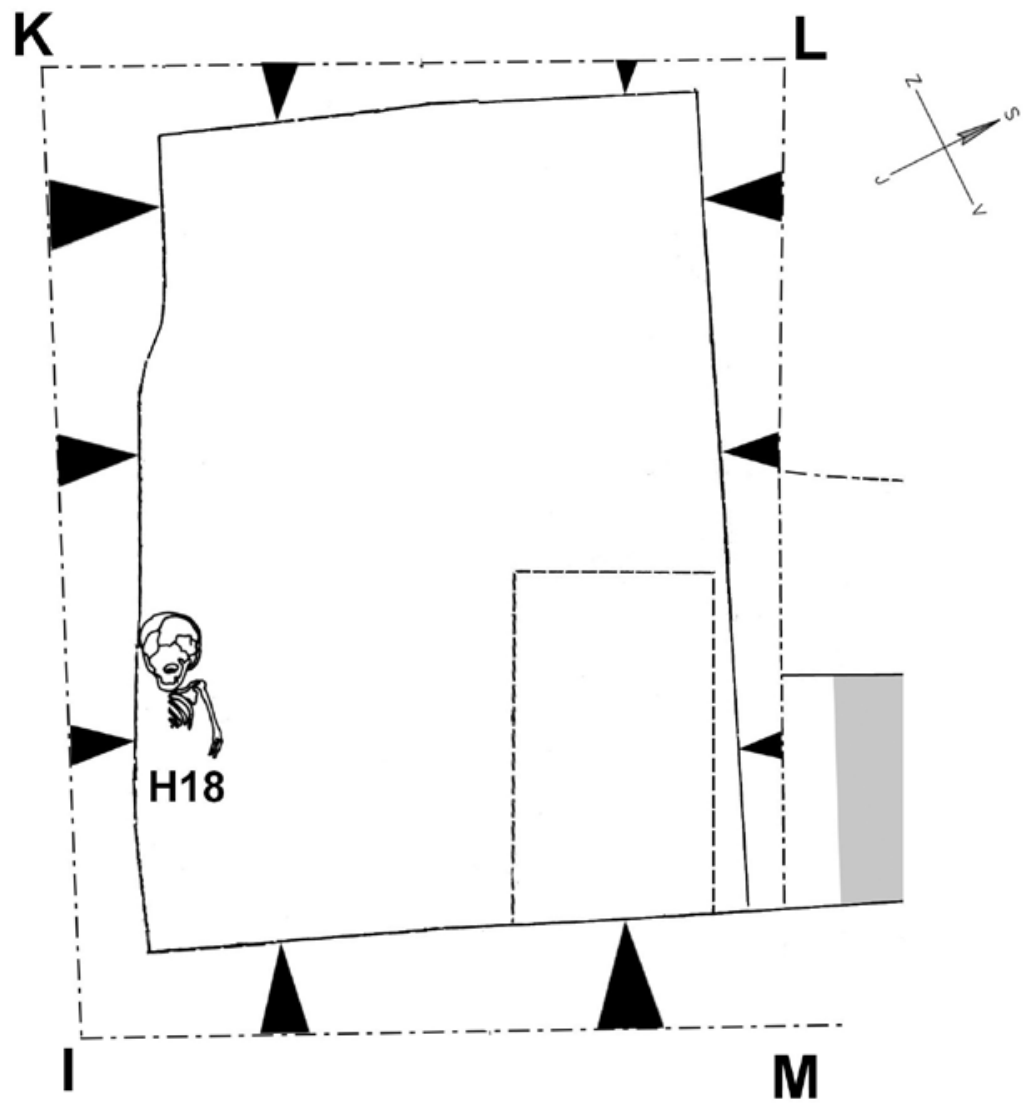

Obr. 5. Vysoké Mýto - Vaňorného náměstí. Sonda 1, spodní úroveň hrobủ. Abb. 5. Vysoké Mýto - Vaňorný-Platz. Sondierschnitt 1, unteres Gräberniveau.

Hrobové situace tak v rámci přeložky plynovodu přinesla pouze sonda 1/2016 (a s ní související plynovodní prrípojka s hrobem 1 ) o rozměrech $2,5 \times 1,5 \mathrm{~m}$ situovaná do stávající komunikace. Recentní konstrukční vrstvy související s komunikací zde nasedaly na šedou písčitojílovitou vrstvu (104) promísenou zlomky keramiky, prejzů, lidskými i zvířecími kostmi, štěrkem i drobným lomovým kamenem a vápnem. Tato vrstva nasedala na vrstvu 106 lišící se od vrstvy 104 pouze menším podílem stavebního materiálu. V těchto uloženinách se ve vrstvách nacházely jednotlivé pohřby od hloubky téměř jednoho metru $(287,10 \mathrm{~m}$ n.m.) pod úrovní stávající komunikace. Do hloubky 1,4 m bylo zjištěno a zdokumentováno celkem 18 hrobů, ovšem žádný ze skeletů nebyl prozkoumán v úplnosti, at' už důvodu omezení sondou (zasahování hrobů mimo její prostor) nebo z důvodu značného vzájemného narušování jednotlivých pohřbů. V hloubce $1,4 \mathrm{~m}$ na dně sondy výzkum dosáhl sterilního podloží, v němž se rýsovaly hrobové jámy s výplní zřetelně odlišitelnou od uloženiny 104 (respektive 106), ty to hrobové jámy se však již nacházely mimo niveletu záchranného výzkumu a zůstaly stavbou i výzkumem nedotčeny (obr. 3-6).

$\mathrm{V}$ případě sondy 4 o rozměrech $2,6 \times 1,5 \mathrm{~m}$ se výkop za využití těžké techniky zastavil na svrchní úrovni hrobů (niveleta $287,17 \mathrm{~m} \mathrm{n}$.m.) s průběžným vzorkováním vrstvy 104 zjištěné (na rozdíl od vrstvy 106, která se však mohla nacházet pod úrovní výzkumu) i zde. I v případě sondy 4 se v této vrstvě nacházely hroby. Následná ruční exkavace odkryla pět hrobů $(\mathrm{H} 20$ H24/2016) představujících svrchní vrstvu etážového pohřebiště, hlouběji uložené hroby se již 

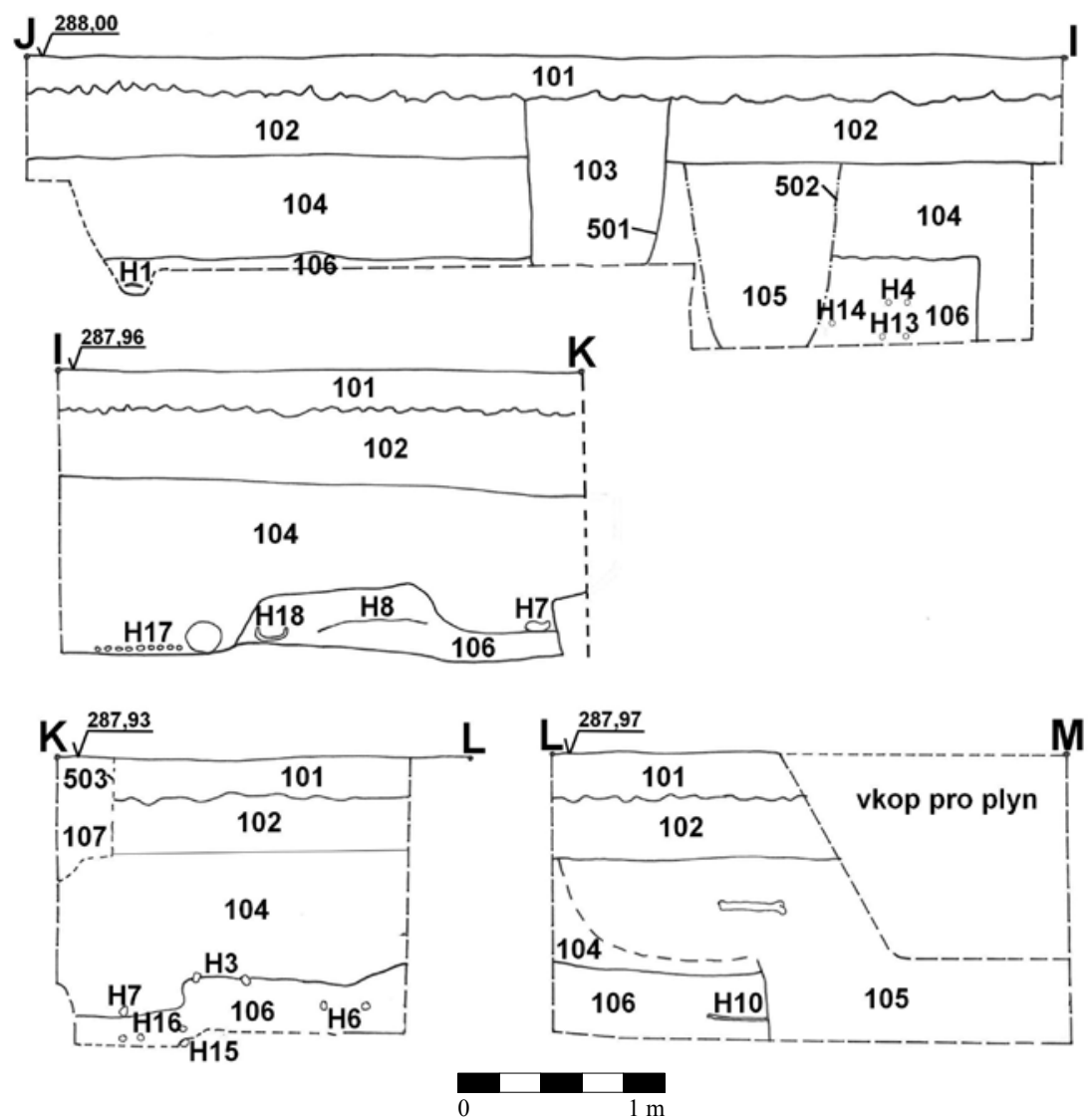

Obr. 6. Vysoké Mýto - Vaňorného náměstí. Sonda 1, kresebná dokumentace řezů.

Abb. 6. Vysoké Mýto - Vaňorný-Platz. Sondierschnitt 1, Zeichendokumentation der Schnitte.

nacházely pod úrovní nivelety kanalizační šachty, a tudíž mimo dosah záchranného výzkumu (obr. 7-8). ${ }^{5}$

Strojově hloubené sondy 5-8 přinesly důležité informace o rozsahu hřbitova a hloubce uložení hrobů. Sonda $8 / 2016$ u zvonice zasáhla recentní navážky - lžíce bagru v hloubce téměř $2 \mathrm{~m}$ narazila na štěrkopísek signalizující prrítomnost inženýrských sítí. Sonda $7 \mathrm{v}$ asfaltové komunikaci před budovou gymnázia zasáhla $0,8 \mathrm{~m}$ mocnou tmavou hlinitou vrstvu nejasného původu, která neobsahovala žádné artefakty ani ekofakty a nasedala na sterilní podloží. Zcela jistě se již nacházela, podobně jako sonda 3, mimo prostor hřbitova. Svrchní úroveň hrobů svědčící o přítomnosti hřbitova jsme zaznamenali v sondách 5 a 6 (obr. 2). ${ }^{6}$

\section{Výzkum v roce 2017}

V průběhu roku 2017 probíhal záchranný výzkum již v rámci rekonstrukce náměstí, kdy jako sondy byly označovány aktuálně skrývané a rekonstruované úseky, pokud bylo nutné

5 Výzkum v sondě 4 jsme vzhledem k dostatku času využili pro seznámení široké veřejnosti s minulostí města a se základy práce archeologa, což se v rámci dne otevřených dveři setkalo se mimořádným ohlasem.

6 Hroby zde byly zastiženy na úrovni nivelety $287,1 \mathrm{~m}$ v sondě 5 a 287,46 m v sondě 6 . 

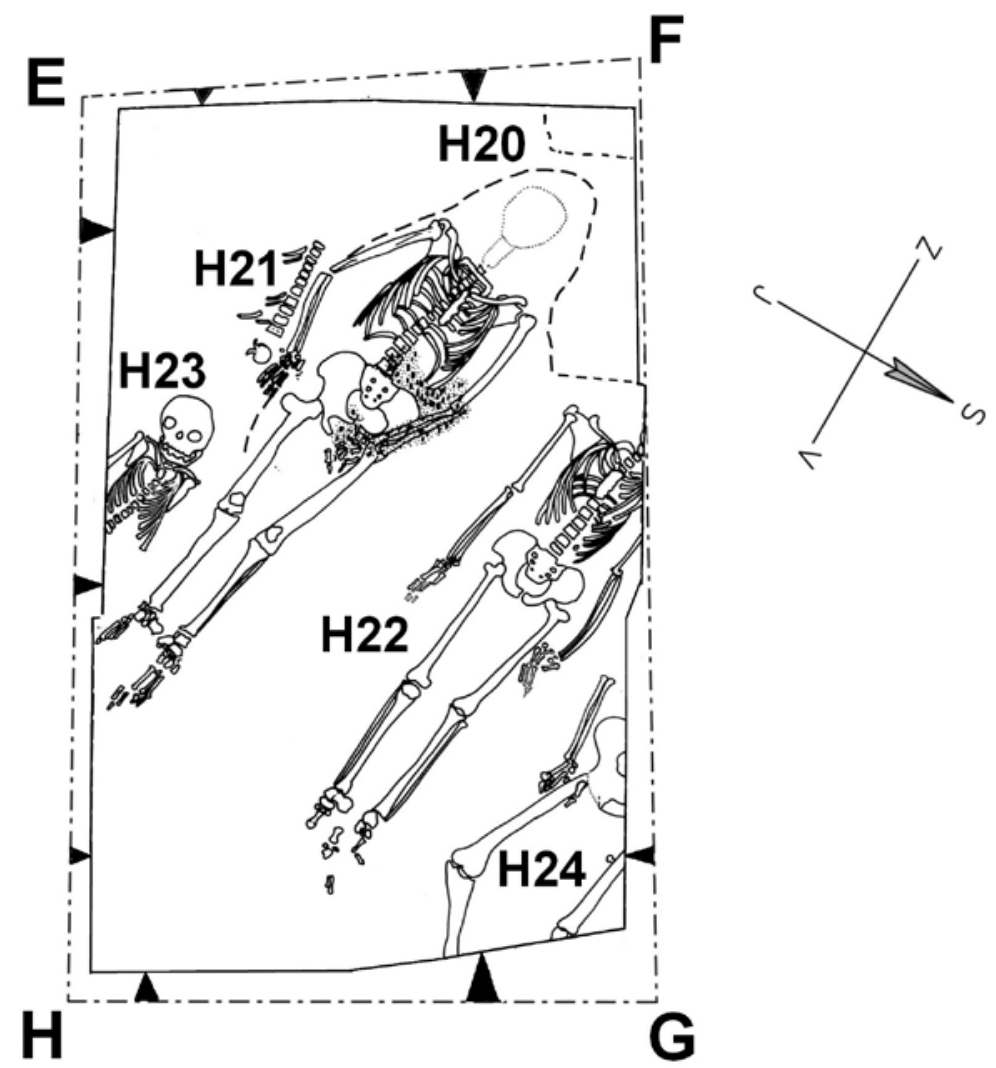

Obr. 7. Vysoké Mýto - Vaňorného náměstí. Sonda 4, svrchní úroveň hrobů.

Abb. 7. Vysoké Mýto - Vaňorný-Platz. Sondierschnitt 4, oberes Gräberniveau.
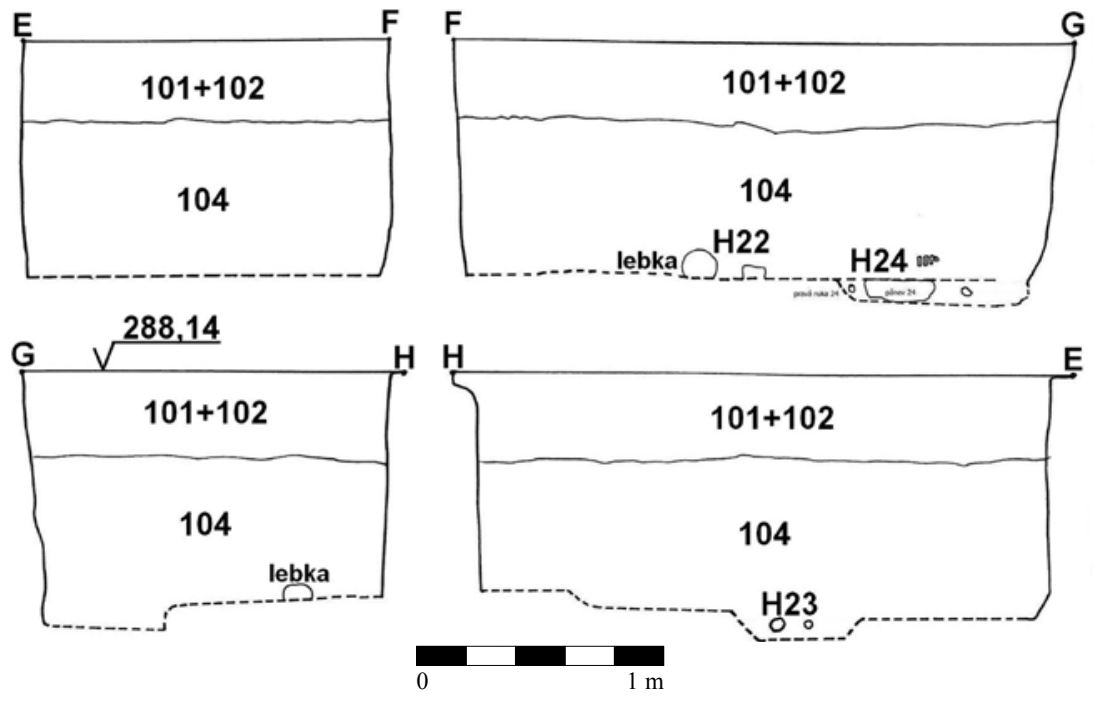

Obr. 8. Vysoké Mýto - Vaňorného náměstí. Sonda 4, řezy.

Abb. 8. Vysoké Mýto - Vaňorný-Platz. Sondierschnitt 4, Schnitte. 


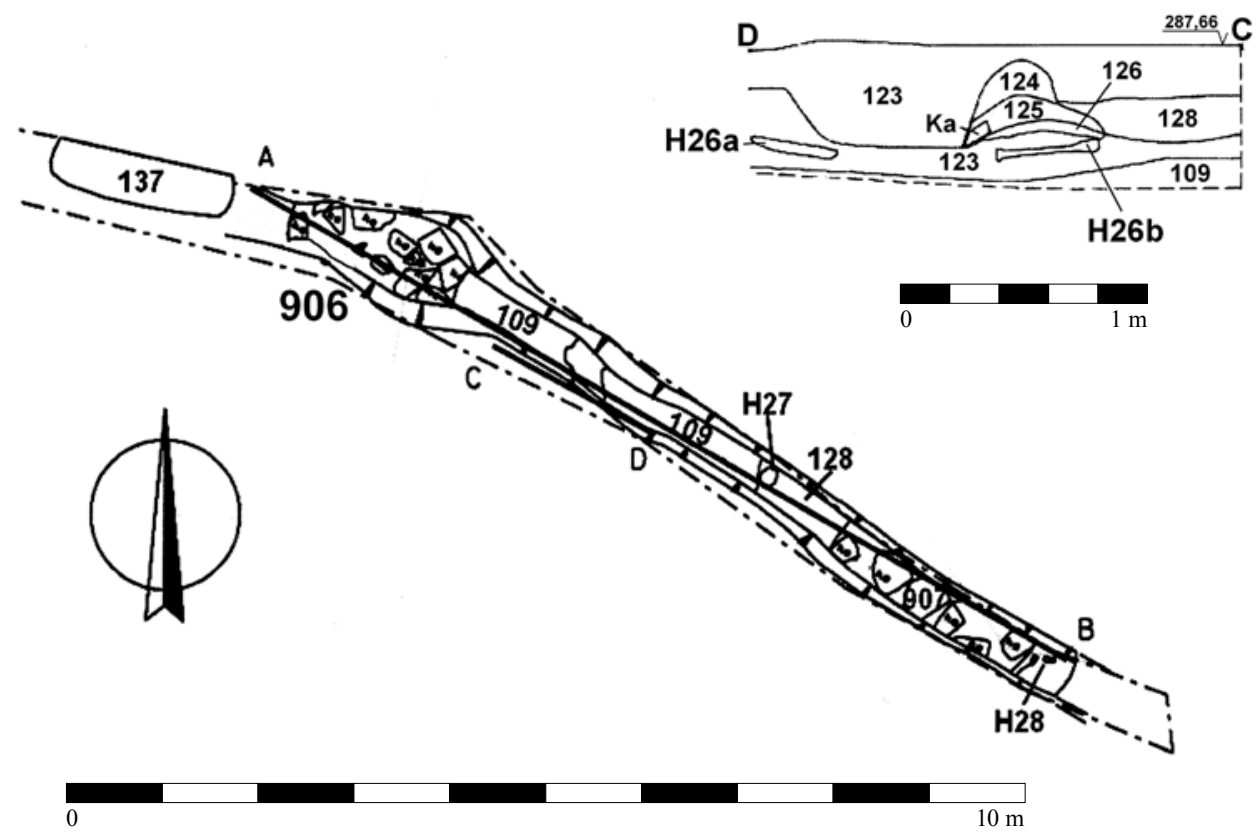

Obr. 9. Vysoké Mýto - Vaňorného náměstí. Sonda 9.

Abb. 9. Vysoké Mýto - Vaňorný-Platz. Sondierschnitt 9.

provést výzkum. V důsledku úpravy projektu na základě informací ze sondáže z roku 2016 jsme se pohybovali v povrchových vrstvách do hloubky okolo $0,6 \mathrm{~m}$, a proto již nebylo nutné hroby zkoumat a exkavovat, ovšem i tak se podařilo zjistit některé důležité informace o rozsahu hřbitova a hloubce uložení hrobů.

Z hlediska poznání rozsahu hřbitova se jako přínosné ukázaly sondy 9, 10 a 11 (obr. 2), především sonda 9 představující vyspádovaný liniový výkop pro deštový svod přinesla některá významná zjištění. ${ }^{7}$

Výkop sondy 9 orientovaný přibližně západovýchodním směrem o hloubce do $0,6 \mathrm{~m}$ prot’al dvě kvalitativně zcela odlišné situace (obr. 9). Východní část výkopu zasáhla kostelní hřbitov, přičemž byla zjištěna a dokumentována svrchní úroveň tř́i hrobů (H26-H28). Mimo to výkop prot’al povrchovou kumulaci silně přepálených lidských kostí (obr. 9, řez C-D, vrstvy 125 a 126). Západní část sondy tvořilo sterilní podloží se zbytky tmavého půdního horizontu bez jakýchkoliv stop hrobů, pouze s recentním narušením. Hranici mezi těmito situacemi tvořila liniová kamenná struktura (906) procházející např́íč sondou.

V sondě 10 (obr. 2) skrývka obnažila hrob H25 na úrovni nivelety $287,70 \mathrm{~m} \mathrm{n.m.} \mathrm{Objev} \mathrm{hro-}$ bů zde byl překvapivý, protože hroby se zde nachází pouhých $0,5-0,6 \mathrm{~m}$ pod povrchem a v rámci celého hřbitova jde o nejmělčeji uložené funerální situace.

Sonda 11 situovaná do komunikace před východním průčelím budovy gymnázia zcela potvrdila předchozí zjištění, že se tento prostor nachází mimo areál hřbitova. Výzkum zjistil úpravu terénu dlážděním a studnu (obr. 10).

7 Sonda 12 obnažila větší torzo dlažby z lomového kamene, sonda 13 pak pouze svrchní úroveň zbytkủ struktur a recentních vrstev projevujících se horizontální stratigrafií. 


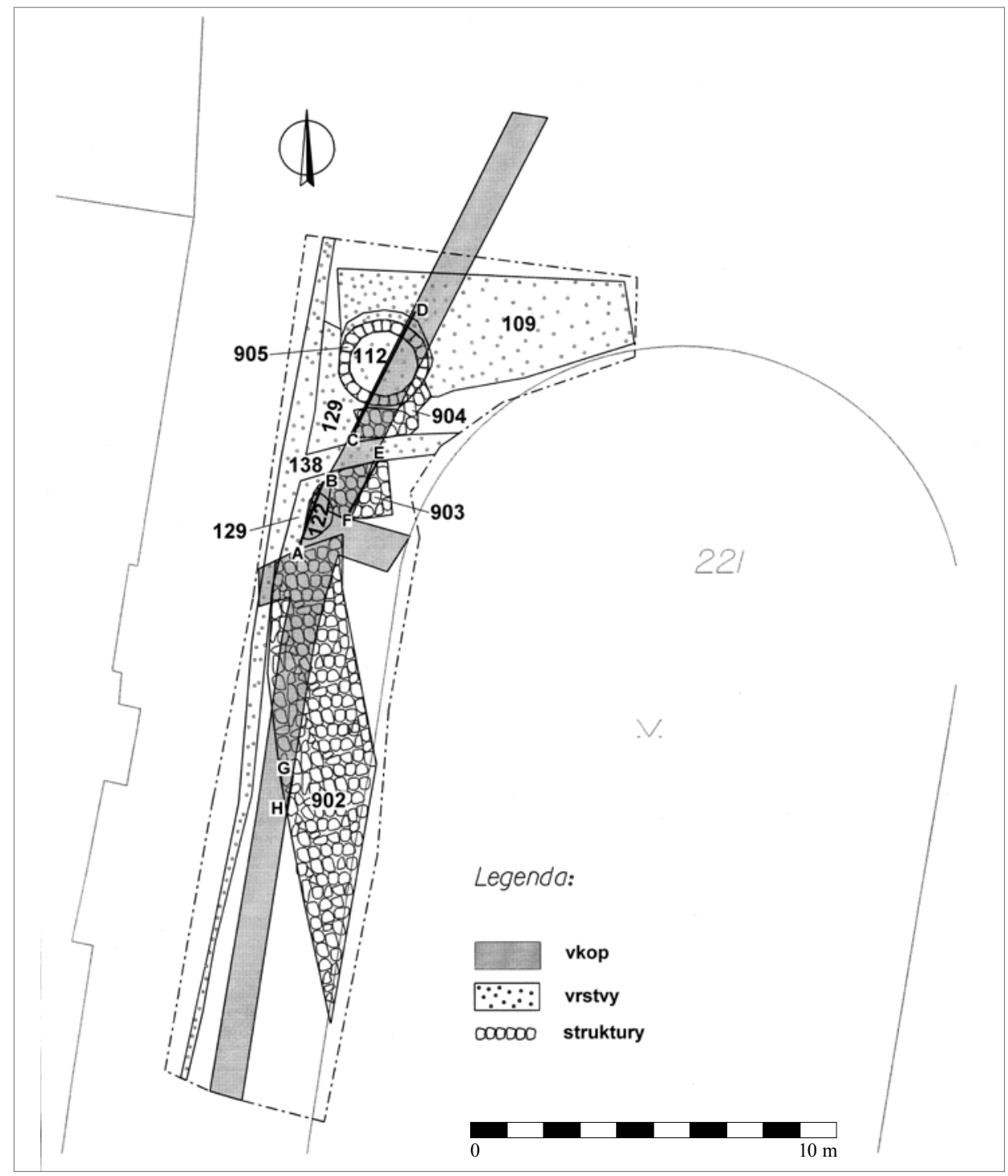

Obr. 10. Vysoké Mýto - Vaňorného náměstí. Sonda 11.

Abb. 10. Vysoké Mýto - Vaňorný-Platz. Sondierschnitt 11.

\section{Archeologické vyhodnocení hrobů}

V letech 2016-2017 se v okolí kostela sv. Vavřince ve Vysokém Mýtě podařilo z větší či menší části zachytit celkem 27 hrobů. ${ }^{8} \mathrm{~V}$ hrobě H1/2016 byl nalezen špendlík ze slitiny mědi u hlavy zemřelého a lze uvažovat o přímé souvislosti tohoto artefaktu se zemřelým. Ostatní hroby byly bez hrobové výbavy, pokud se u nich setkáváme s movitými nálezy (keramikou), jde

8 I když se v textu objevuje označení H28, počet prozkoumaných hrobů skutečně činí 27, protože objekt označený H19 se jako hrob nepotvrdil a označení bylo zrušeno. Kromě posledních hrobů objevených při rekonstrukci náměstí byly zbývající hroby (respektive jejich části zasahující do sondy) vyjmuty a po antropologické analýze vráceny investorovi k přepohřbení na vhodném místě. 
o zjevnou intruzi související s hrobovým zásypem. Proto jsme při pokusu o datování hrobů odkázáni výhradně na stratigrafická pozorování a písemné prameny. $Z$ tohoto hlediska jsou velmi důležité vrstvy 104 a 106, do nichž byly uloženy pohřby v sondách 1 a 4 .

$\mathrm{Z}$ těchto uloženin disponujeme celkem 106 kusy velmi heterogenní, fragmentarizované a většinou atypické keramiky (obr. 13). Největší zlomek nedosahuje velikosti $9 \mathrm{~cm}$, velikost většiny zlomků se pohybuje v rozmezí $2-5 \mathrm{~cm}$. Jejich opotřebení a stav lomů ukazují na terciární uložení, a tedy opakované přemistování. Z tvarů umožňují identifikaci pouze hrnce a hrnce s uchem, poklička, ojediněle byl zaznamenán i zlomek mísy a okraje trojnožek. Výzdoba se vyskytuje pouze vzácně v podobě červeného malování na světlé hrnčině a vodorovného rýhování/žlábkování. Redukčně a oxidačně pálené zboží je zastoupeno zhruba ve stejném poměru. V atypických zlomcích se objevil střep vyrobený v hradištní tradici šedých až hnědavých odstínů ostř̌ený slídou, odkazující do počátků 14. století či ještě věku předcházejícího. Na opačném konci časového spektra stojí zlomky opatřené jednostrannou či méně často oboustrannou glazurou hnědavých a žlutavých odstínů. Progresivní prvky rovněž vykazuje drobný tenkostěnný střep s vyhnutým vně ovaleným okrajem a hladkým povrchem, jehož keramická hmota je oproti ostatním zlomkům výrazně méně porézní a působí až slinutým dojmem. Když pomineme zjevnou starší intruzi, keramika z Vysokého Mýta z vrstev 104 a 106 vykazuje podobné znaky jako soubor z Chrudimi - Husovy ulice (Frolík-Sigl 1990). Nejmladší zlomky nejsou starší než první polovina 16. století, u některých zlomků nemůžeme s jistotou vyloučit (ovšem ani potvrdit) datování ještě mladší. ${ }^{9}$

Již samotná přítomnost vrstvy $104+106 \mathrm{v}$ sondě $1 \mathrm{~s}$ ověřenou mocností téměř jednoho metru představuje závažnou skutečnost, protože ukazuje na poměrně razantní terénní změny, ke kterým v okolí kostela došlo dle rozboru nálezů někdy v pokročilém 15. či spíše v první polovině 16. století, když některé mladší zlomky se do vrstvy mohly dostat až při opakovaném otevírání hrobových jam. Když vezmeme v potaz stavební charakter této vrstvy, jeví se jako nejpravděpodobnější vysvětlení její souvislost se stavebními úpravami kostela po požáru v roce 1461, případně po dalším požáru kolem roku 1517, přičemž posledně jmenovanou událost z pramenů spíše jen tušíme. Vzhledem k mocnosti vrstvy a úrovni konstrukčních prvků kostela, podle kterých se úroveň terénu od vrcholného středověku nijak dramaticky (v rádech metrů) neměnila, musíme počítat s tím, že vrstva 104+106 nepředstavuje jenom pouhou planýrku stavební suti vzniklou při rekonstrukci, ale že jejímu navršení předcházelo alespoň částečně snížení terénu. Př́ičiny ani šiři terénních změn však bohužel neznáme, k objasnění jejich plošného rozsahu nijak nepřispěla vzhledem k omezené hloubce ani skrývka při rekonstrukci náměstí v roce 2017. Jisté však je, že po uložení této vrstvy (či přesněji řečeno souvrství) se do vzniklých uloženin intenzivně pohřbívalo, a to do té míry, že docházelo k vícenásobným superpozicím jednotlivých těl a dnes jsme schopni identifikovat tři vrstvy hrobů. I když délku období, při kterém docházelo k pohřbívání do vrstev 104+106, nedokážeme stanovit, s ohledem na hustotu hrobů je jisté, že to nebyla otázka pouhých měsíců. Na základě komparace písemných zpráv a archeologicky zjištěných skutečností by měly být tyto hroby (patrně s výjimkou hrobů nejspodnějších) datovány do první poloviny (či spíše druhé čtvrtiny) 16. století, přičemž k zaplnění nově získaného prostoru pohřbenými těly došlo v relativně krátké době v řádech let až jednoho či dvou desetiletí. Zcela ovšem nemůžeme vyloučit ani možnost, že se zde oproti písemným zprávám v pohřbívání ještě s určitou setrvačností po nějakou pokračovalo, a to paralelně s pochováváním na nově vzniklém hřbitově kolem kostela Nejsvětější Trojice.

Relativně starší, tedy ještě vrcholně středověké, mohou být (a s velkou pravděpodobností i jsou) alespoň některé hroby uložené při bázi sondy 1 . Ukazuje to nejen jejich pozice těsně nad podložím, takže terénní zásahy kladené do souvislosti s opravou kostela se jich nemusely dotknout, ale oproti kosterním pozůstatkům z vyšších vrstev i výrazně horší stav kostí - již se rozpadaly. $\mathrm{V}$ absolutních datech se však vyjádřit nedokážeme.

9 Za konzultaci jsme zavázáni Radku Bláhovi a Janu Frolíkovi. 
Pouze omezené informace přinesl výzkum, co se týče zvyklostí při pochovávání. Zesnulí jsou podle dobových zvyklostí uloženi hlavou k západu až severozápadu (v případě sondy 1/2016). Jak je u tohoto typu výzkumu obvyklé, v rámci pohřební vrstvy nebylo prakticky možné identifikovat vkopy pro hrobové jámy. Mladší hroby často narušují hroby starší, čímž dochází k několikanásobným superpozicím (zejména obr. 4). S jedinou výjimkou nebyly pozorovány žádné stopy signalizující přítomnost rakve, na absenci rakví můžeme usuzovat i z dochování skeletů. Neshledali jsme žádné posuny, které by dokládaly uložení těl v dutém prostoru. Rovněž v případě superpozic jednotlivých hrobů se narušení staršího pohřbu omezuje na bezprostřední okolí mladších skeletů, což rovněž neukazuje na pochovávání v rakvích. O nepoužívání rakví může s výhradami svědčit také nepřítomnost hřebů. K pohřbu v rakvi či na dřevěné desce došlo pouze v př́ípadě hrobu 15/2016, o čemž svědčí zbytek zetlelého plochého dřeva. U hrobu 20 se oblasti kyčlí dochoval ve vápně otisk textilie. I když se přibližně od 14. století začíná projevovat vývoj od pohřbívání s rukama podél těla $\mathrm{k}$ pohřbům s rukama na hrudi či břiše (ovšem v některých př́ípadech se vývoj ubíral přesně opačným směrem, viz Frolík 2017, 195-196), všechny zkoumané hroby, u nichž bylo možné sledovat polohu rukou, se vyznačovaly rukama nataženýma podél těla, což potvrzuje pozorování, že poloha horních končetin nepředstavuje nutně chronologicky významný prvek (Čechura 2010, 114).

Rekonstrukce Vaňorného náměstí přinesla ve své západní části také určitá zjištění týkající se rozsahu hřbitova. Důležité informace o tom, jak zde situace vypadala před razantními úpravami zejména ve druhé polovině 19. století, přináší mapa stabilního katastru (obr. 14). Před západním průčelím kostela sv. Vavřince šikmo k němu stála budova starého děkanství. Jižně od kostela vidíme budovu staré školy, mezi ní a starým děkanstvím zřetelně rozeznáváme průběh hradební zdi stáčející se kolem kostela, identifikovat můžeme dokonce i zbytek bašty. Ze srovnání tohoto pramene s dnešními mapovými podklady můžeme dovodit, že staré děkanství stálo šikmo přibližně uprostřed dnes zatravněného parkového prostoru mezi gymnáziem a průčelím kostela sv. Vavřince. V těchto místech liniové výkopy při rekonstrukci náměstí skutečně protaly recentní vrstvy s četným odpadem charakteru navážek a planýrek, byly ale př́liš mělké na to, aby přinesly nějaké smysluplné informace. Se starým děkanstvím by teoreticky mohla souviset studna zjištěná v sondě 11 , případně i přiléhající dlažba. Sonda 9 kolmo prot’ala základy masivní zdi široké $1,9 \mathrm{~m}$ stavěné $\mathrm{z}$ lomového opukového kamene pojeného okrovou hlínou (struktura 906), která probíhala v zásadě paralelně se západním průčelím kostela sv. Vavřince. Právě především orientace zdi spolu s její masivností nedovoluje ztotožnění této struktury se zaniklým starým děkanstvím, poprrípadě se stavbou vyplňující s číslem 197 vnitřní prostor bašty a přiléhající k jižní zdi starého děkanství. Mapa stabilního katastru zároveň nenabízí žádné jiné jednoznačné vysvětlení tohoto stavebního prvku, zed' ale jednoznačně vymezuje prostor hřbitova. Interpretace této zdi jako základu městské hradby by sice dobře vysvětlila její sílu i fakt, že tvoří hranice hřbitova, ovšem její poloha je i přes určité zkreslení přece jenom v rozporu se situací zachycenou stabilním katastrem. Vysvětlení zdi jako hřbitovního ohrazení zase naráží na otázku smysluplnosti takto masivního ohrazení v bezprostřední blízkosti městské hradby. Při snaze o interpretaci situace v sondě 9 jsme zřetelně limitováni jejím nevelkým plošným rozsahem na straně jedné a omezenou hloubkou skrývek jejího širšího okolí při rekonstrukci náměstí na straně druhé. Každopádně je velká naděje, že odpověd' na hledané otázky zůstává pod dnešním povrchem Vaňorného náměstí ukryta v bezpečí pro prř́ští generace.

\section{Antropologická analýza}

Antropologickou analýzu bylo možné provést na kosterních pozůstatcích dvaceti tř́ jedinců za pomoci standardních metod kosterní antropologie, které byly voleny s ohledem na stav konkrétních pozůstatků.

Věk byl hodnocen aspektivně, především podle celkové maturace kostí (Schaefer et al. 2009). U dospělých jedinců byly pro zpřesnění odhadu dožitého věku použity metody sledující strukturální změny na povrchu facies auricularis pánevních kostí (Schmitt 2005) a strukturální 


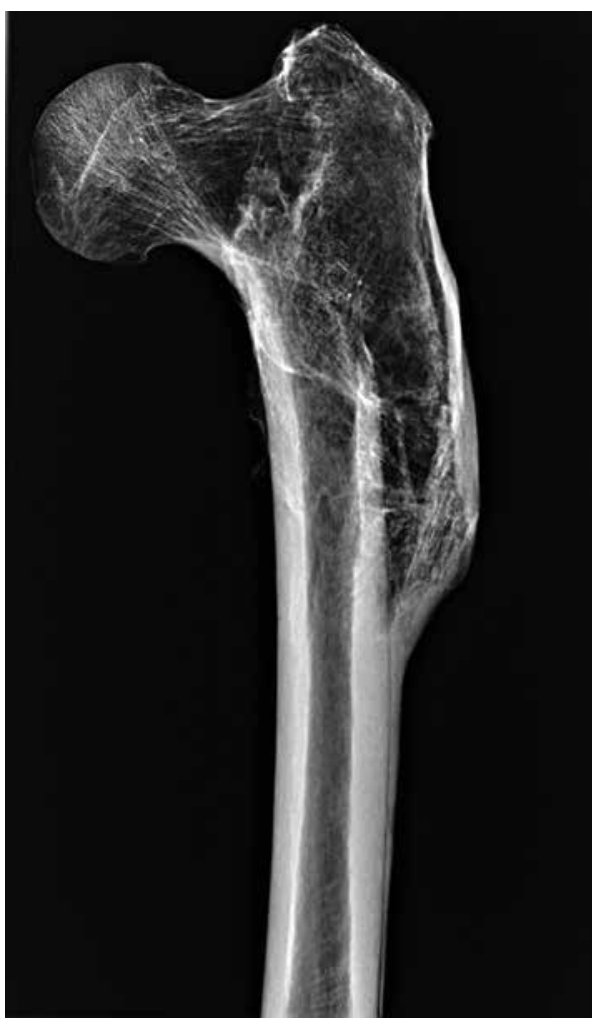

Obr. 11. Vysoké Mýto - Vaňorného náměstí. Sonda 4, hrob 24 - rentgenový snímek zhojené subtrochanterické zlomeniny levé stehenní kosti.

Abb. 11. Vysoké Mýto - Vaňorný-Platz. Sondierschnitt 4, Grab 24 - Röntgenbild der ausgeheilten subtrochantären Fraktur des linken Oberschenkelknochens. změny na povrchu facies symphysialis pánevních kostí (Brooks-Suchey 1990). Dále byly sledovány i degenerativně produktivní změny na páteři, respektive byla zohledňována přítomnost osteofytů 3. stupně, jejichž výskyt může být u jedinců mužského pohlaví spojován $\mathrm{s}$ věkem nad 40 let (Stloukal-Vyhnánek 1976). Dožitý věk u nedospělých jedinců byl určován na základě metrického hodnocení postkraniálního skeletu (Stloukal-Hanáková 1978 a Florkowski-Kozlowski 1994, oboje cit. podle Stloukal 1999, 251, 252) a dále podle mineralizace a prořezávání zubů (Ubelaker 1978 cit. podle Stloukal 1999).

Pohlaví bylo určováno pouze u dospělých jedinců, a to na základě aspektivního hodnocení rozvoje znaků na lebce (Walrath-Turner-Brůžek 2002), na pánevní kosti (Brůžek 2002) a dále na základě metrického hodnocení kostí postkraniálního skeletu. Z metrických metod byl využit program DSP hodnotící rozměry na pánevní kosti (Murail et al. 2005), dále metrická charakteristika pažní a stehenní kosti (Černý-Komenda 1980), metrické hodnocení hlezenní kosti (Novotný 1985), obratlů (Mac-Laughlin-Oldale 1992 cit. podle Stloukal 1999), klíční kosti (Iordanidis 1961 cit. podle Stloukal 1999), vřetenní kosti (Singh et al. 1974 cit. podle Stloukal 1999), čéšky (Dofková 1995 cit. podle Stloukal 1999) a holenní kosti (Iscan-Miller-Shaivitz 1984 cit. podle Stloukal 1999). V jednom případě byla použita metoda hodnotící rozměry korunek trvalého chrupu (Iscan-Kedici 2003).

Výška postavy u všech jedinců s př́ítomnou dlouhou kostí vhodnou k metrické analýze byla vypočítána metodou platnou pro archaické populace a obě pohlaví (Sjøvold 1990), a to na základě rozměru největši délky dané kosti (Drozdová 2004).

Ve zkoumaném souboru se nacházely kosterní pozůstatky třinácti dospělých mužů, tř́ dospělých žen a pěti dětí, u dvou jedinců nebylo možné určit žádné demografické parametry. Ze všech šestnácti dospělých jedinců bylo osm starších čtyřiceti let (sedm mužů a jedna žena), z pěti dětí byly dvě mladší šesti let (kategorie infans Ib) a zbylé tři děti spadaly do kategorie infans II (6-14 let). Výšku postavy bylo možné vypočítat u osmi dospělých jedinců, u sedmi mužů se střední hodnota pohybovala v rozmezí $166-175 \mathrm{~cm}$, u jedné ženy byla výška určena na přibližně $163 \mathrm{~cm}$.

Kromě určení základních demografických parametrů byla pozornost věnována i patologickým změnám na kostech, kloubech a dentici. Tyto byly posuzovány makroskopicky, za pomoci dvou publikací v oboru paleopatologie (Mann-Murphy 1990; Horáčková-Strouhal-Vargová 2004). Mezi nejčastěji pozorované patologické znaky patří ty, které jsou spojeny s degenerativním onemocněním páteře - byly pozorovány u sedmi jedinců. Jedná se o projevy deformační spondylózy a spondylartrózy, včetně výskytu Schmorlových uzlů. Jsou zde zastoupeny i artrotické změny apendikulárních kloubů (pozorovány u dvou jedinců) a entezopatie, např́iklad v podobě patních ostruh (pozorováno u třech jedinců). U dvou dětských skeletů byly zjištěny tzv. 


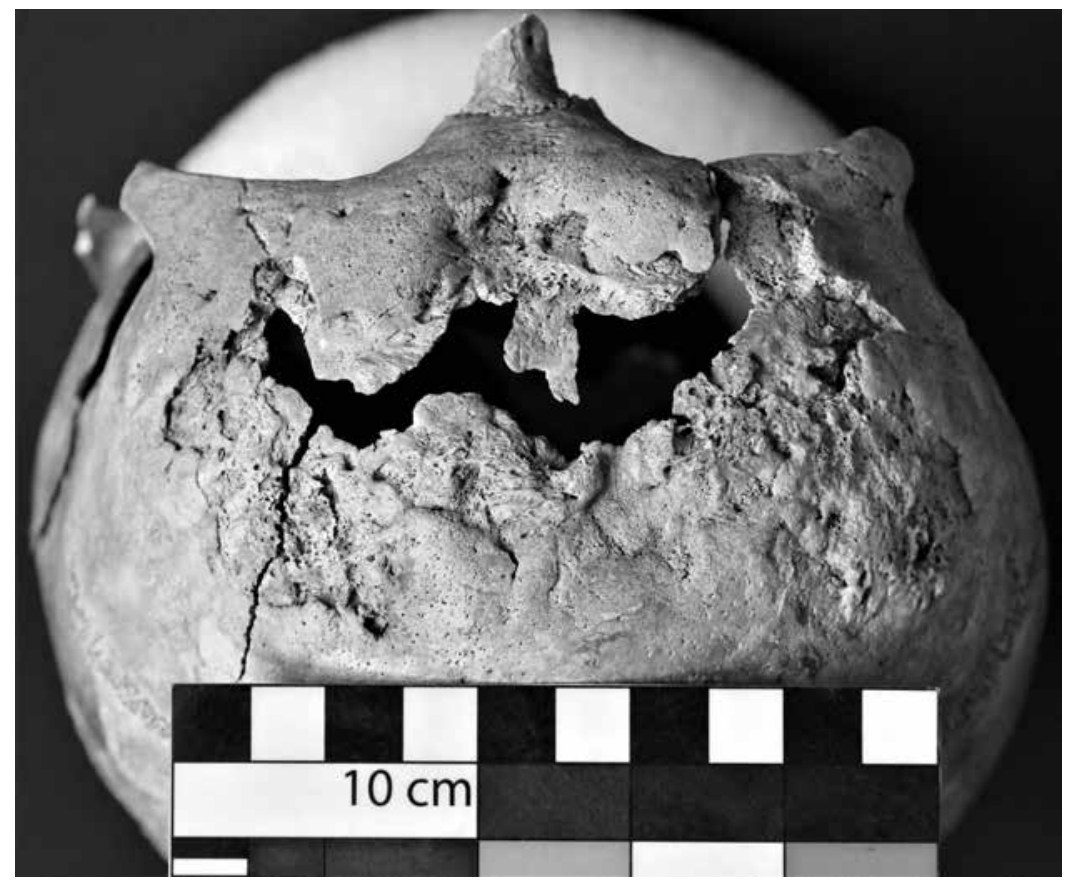

Obr. 12. Vysoké Mýto - Vaňorného náměstí. Snímek postižení lebečních kostí z hrobu 4. Foto J. Š́nová. Abb. 12. Vysoké Mýto - Vaňorný-Platz. Aufnahme der Schädelknochenerkrankung aus Grab 4. Foto J. Š́nová.
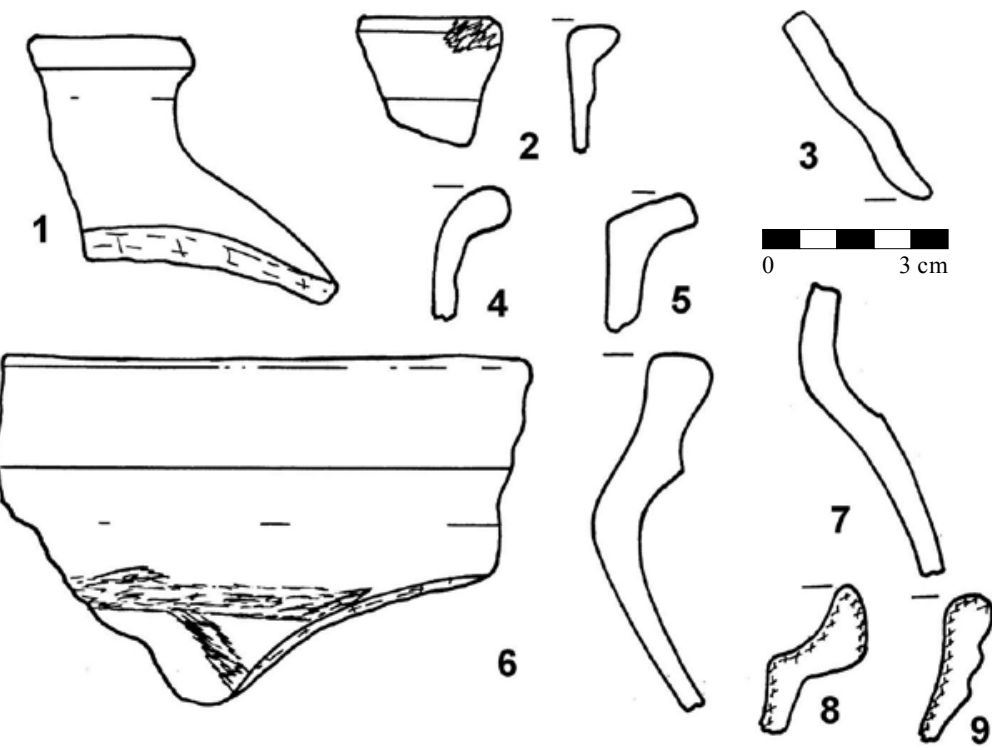

Obr. 13. Nálezy keramiky z výzkumu. 1-5 - sonda 4/2016, vrstva 104; 6-9-sonda 1/2016, vrstva $104+106$. Abb. 13. Bei der Grabung gemachte Keramikfunde. 1-5 - Sondierschnitt 4/2016, Schicht 104; 6-9 - Sondierschnitt 1/2016, Schnitt 104+106. 
cribra orbitalia, tedy pórovité struktury na stropu očnice, jejichž výskyt je spojován s poruchami výživy, hypovitaminózou $\mathrm{C}$ a obecně s deficiencí železa, u středověkých či raně novověkých pohřbů se jedná o celkem běžný fenomén. U dvou jedinců byly dokumentovány paleopatologické ukazatele na dentici, a to tvarové změny ztotožněné s vývojovým defektem tvrdých zubních tkání ve formě horizontálních linií. Jedná se o tzv. hypoplazii zubní skloviny, která odráží nespecifické indikátory stresu prodělaného v průběhu dětství. Takové defekty skloviny mohou být spojeny s nutriční deficiencí, nebo s prodělaným infekčním onemocněním. Nespecifické zánětlivé změny se objevily na kosterních pozůstatcích pěti jedinců.

Kromě kosterních pozůstatků z hrobů byl antropologicky hodnocen také vzorek zlomků přepálených kostí nalezených v sondě 9 . Některé fragmenty kostí bylo možné s jistotou identifikovat jako lidské kosterní pozůstatky. Různorodý charakter zabarvení jednotlivých fragmentů ukazuje na to, že jednotlivé kosti byly vystaveny různým teplotám. Jako málo pravděpodobné se proto jeví cílené spalování lidských kostí, např́íklad z důvodu omezené kapacity kostnice doložené archeologickým výzkumem u kostela sv. Václava v Lažanech (Frolík 2017, 199). Nálezová situace dovoluje spíše zvažovat sekundární přemístění ostatků z míst zasažených požárem, což by dobře korespondovalo s dějinami kostela.

Za zvláštní zmínku z paleopatologického hlediska jistě stojí kosterní pozůstatky mužů z hrobu 4 a 24 . U muže z hrobu 24 , u něhož výzkum zasáhl pouze dolní končetiny, byla zjištěna zhojená subtrochanterická zlomenina levé stehenní kosti s dislokací, při které došlo k výraznému zkrácení kosti (rentgenový snímek na obr. 11). Zlomenina tohoto typu s velkou pravděpodobností vznikla pádem z velké výšky (Hirt et al. 2011). Posun a následné zkrácení kosti způsobil přirozený tah kosti. Dolní končetina tedy nebyla zafixována, tím pádem ani odborně ošetřena. Produkt hojení zlomené kosti, mohutný svalek, který se kolem zraněného místa vytvořil, je hladký, což dokládá úplné zhojení tohoto závažného zranění. Kromě zlomené levé stehenní kosti trápila muže velmi výrazná artróza pravého kyčelního kloubu. Na hlavici levé stehenní kosti se nacházejí nepř́iliš výrazné znaky přicházející artrózy, ale stav v pravém kyčelním kloubu je nepoměrně vážnější. Manifestace artrózy pravého kyčelního kloubu zřejmě koreluje s poúrazovým zkrácením levé dolní končetiny jako důsledek přetěžování končetiny pravé. Každopádně at' už byly př́ičiny a následné děje vedoucí k patologickým změnám jakékoliv, muž jistě za svého života trpěl výraznými bolestmi.

U muže z hrobu 4 pak byl pozorován soubor patologických ukazatelů, které s velkou pravděpodobností odpovídají onemocnění získané syfilis, respektive projevu jejího třetího stadia. $\mathrm{Na}$ čelní kosti a levé temenní kosti byla pozorována tzv. gummata, tedy specifická nekróza kostní tkáně, typická právě pro toto onemocnění. Další ložiska eroze a deformace kostí se nacházely na dolní čelisti, na obou klíčních kostech a na obou lopatkách. Dále na dlouhých kostech končetin se nacházela ložiska zánětu, který nemusí mít přímou souvislost se syfilitickou infekcí.

\section{Syphilis sive morbus gallicus}

Syfilis je chronicky probíhající infekční onemocnění způsobené bakterií Treponema pallidum. Onemocnění bylo pojmenováno podle pasáka sviní jménem Syphilus, a to v knize italského básníka a lékaře Girolama Fracastora (1478-1553) s názvem Syphilis sive morbus gallicus (Syfilis aneb francouzská nemoc) vydané v roce 1530 . Z období přelomu 15. a 16. století pocházejí označení jako Morbus gallicus, Mala frances či Malum francicum (vše francouzská choroba), objevovala se ale i označení další. Dnes nejužívanější medicínské označení syfilis bylo etablováno až v 18. století. V předchozích obdobích používala lékařská věda termíny jako Morbus venereus nebo Lues venerea - venerický mor (první třetina 16. století). Zde je možné spatřovat původ českého označení př́ijice. Pojmenování pochází od lékaře Antonína Jungmanna (1775-1854), jenž název odvodil od jména slovanské bohyně lásky jménem Př́ije (Horáčková-Strouhal-Vargová 2004; Vlček 1996).

Podle způsobu onemocnění rozlišujeme dvě formy syfilis. První formou je získaná forma syfilis (syphilis acquisita), u které dochází k přenosu onemocnění v průběhu života jedince, a to 
při pohlavním styku (nejčastější), dále krevní cestou nebo př́ímým kontaktem sliznic. Druhou formou je vrozená forma syfilis (syphilis congenita), u které dojde k přenosu transplacentárně z matky na plod ještě před narozením. U získané syfilis se popisují tři stadia průběhu nemoci. První stadium je charakteristické vytvořením takzvaného tvrdého vředu (ulcus durum), jež je doprovázeno zduřením okolních lymfatických uzlin. Zhruba po pěti klidových týdnech následuje stadium druhé. Infekce se při ní šírí cestou lymfy a krve po celém organismu a je provázeno pestrým spektrem kožních a slizničních projevů. Třetí stadium je pozdním a neinfekčním projevem onemocnění objevujícím se po různě dlouhém období latence. Tato fáze je charakteristická rozvojem orgánových změn, poškozením cév a centrální nervové soustavy. Jedním z projevů poškození nervového systému bývá tabes dorsalis, což je manifestace onemocnění objevující se patnáct až třicet let po syfilitické nákaze. Tabes dorsalis se projevuje postupnou ztrátou polohocitu, poruchami chůze či citlivosti dolních končetin. Ve třetím stadiu může být zasažen také skelet nakaženého. Kostní projevy mají charakter chronického zánětu postihujícího především dlouhé kosti končetin (typicky holenní a lýtkové kosti). Dále bývá postižena obličejová část lebky, zpravidla destrukcí oblasti nosu spolu s tvrdým patrem. Na plochých lebečních kostech pak syfilitická infekce způsobuje projevy označované jako suchý kostižer (caries sicca). Tento proces ničí kostní tkáň a spolu s její novotvorbou se v mase lebečních kostí tvoří otvory. Pokud se na kostech klenby lební nachází větší množství ložisek kostižeru, pak celý povrch lebky vypadá, jako by byl „,prožraný“ červotočem. Právě takové postižení lebečních kostí, které je typické pro třetí stadium, vykazují kosterní pozůstatky muže z hrobu H4 (obr. 12). U vrozené formy syfilis se první stadium nemoci nevyskytuje, u postiženého se bezprostředně rozvíjí orgánová poškození. Charakteristickým příznakem vrozené syfilis je nedostatečný vývoj zubní skloviny u první stoličky - tzv. Moonův molár, nebo u řezáků - tzv. Hutchinsonovy zuby (Aufderheide-Rodríguez-Martín 2011; Horáčková-Vargová 2009; Horáčková-Strouhal-Vargová 2004).

Do dnešní doby není uspokojivě objasněno, kdy syfilis vznikla a kde byl původní zdroj této infekce. V současnosti jsou etablovány tři základní teorie snažící se objasnit tuto problematiku. Zastánci první z nich, tzv. kolumbovské teorie, se domnívají, že syfilis byla onemocněním obyvatel amerického kontinentu a do Evropy se dostala spolu s Kolumbovými námořníky. Bezprostředně po jejich návratu (po roce 1493) se totiž syfilis pandemicky šířila Evropou. Další teorie, prekolumbovská, pracuje s hypotézou nevylučující možnost výskytu syfilis v Evropě před Kolumbovým návratem. Proti oběma teoriím hovoří skutečnost, že pokud by Kolumbovi námořníci přenesli syfilis z Ameriky do Evropy, pak by na kostrách datovaných do předkolumbovské éry musely být objeveny podobné morfologické změny i na americkém kontinentu. Ty však zatím nebyly spolehlivě prokázány. To platí i pro obdobné nálezy z různých míst „prekolumbovské“ Evropy (Skotsko, Norsko, Balkán), kde chorobami podobného typu trpívaly celé populace. Nelze však bezpečně tvrdit, že se jedná o jedince, kteří by trpěli syfilitickou nákazou. Navíc v evropských historických pramenech datovaných před rok 1493 nebyla popsána či definována choroba samotná. Stoupenci prekolumbovské teorie tento rozpor vysvětlují špatnou úrovní tehdejší medicínské péče a záměnou syfilitických kožních projevů s projevy leprózními. Nejvíce zastánců má v současné době třetí teorie - unitární. Ta pracuje s předpokladem výskytu syfilis již u paleolitických obyvatel Afriky v podobě nepř́liš závažného kožního onemocnění. Z afrického kontinentu se poté nemoc šířila jak do Ameriky, tak i do Evropy a její projevy se odlišily různými př́rodními, klimatickými a socioekonomickými podmínkami. Syfilis tak existovala nezávisle na sobě na obou kontinentech ještě před Kolumbovým objevením Ameriky. Podle této teorie tedy mají tvarově odlišné treponemální bakterie Starého a Nového světa společného pravěkého předchůdce. Příčina evropské postkolumbovské pandemie je vysvětlena prenosem infekce do odlišných klimatických a sociálních podmínek - americký druh bakterie se stal pro vnímavou evropskou populaci vysoce patogenním. Nástup molekulárně biologického výzkumu z posledních let dovolil nahlížet na teorii původu syfilitické nákazy z jiného úhlu. I když nám tyto výzkumy zatím nedovolují bezpečně říci, která z teorií je skutečně pravdivá, přinesly poznatek o genetické odlišnosti jednotlivých poddruhů treponemální bakterie. Poddruhy tedy nemají společného předka, tím pádem je zřejmě zneplatněna unitární teorie. Nevyřešených otázek na poli 
původu infekce je mnoho a je možné, že otázka původu zůstane nezodpovězena (k problematice Aufderheide-Rodríguez-Martín 2011; Horáčková-Strouhal-Vargová 2004; Nechvátal 2009; Roberts-Manchester 2005; Vlček 1996).

Bez ohledu na nejasnosti v původu treponemální bakterie je jisté, že se koncem 15 . a začátkem 16. století diskutovaná infekce šírila epidemicky Evropou a měla charakter infekce akutní a smrtící. V průběhu následujících století se postupně zvyšovala odolnost populace vůči nákaze a nemoc přešla do chronických forem (třetí stadium choroby). Rychlé šíření nákazy bývá spojováno s postupem španělského žoldnéřského vojska provázejícího francouzského krále Karla VIII. na jeho tažení za ziskem neapolského trůnu v roce 1494 (odtud pojmenování francouzská, galská či neapolská nemoc). Syfilitická nákaza se na konci 15. století objevila v českých zemích zřejmě ve spojitosti s přímou účastí českých žoldnéřů na Karlově tažení. Již v roce 1500 se v Praze nakažení vyskytovali v takovém množství, že měli údajně ležet v ulicích nebo kramářských boudách na Koňském trhu. Úředním nařízením byli posléze vyhnáni za Pořičskou bránu, kde pro ně byl v bývalém útulku pro malomocné založen špitál svatého Pavla (Horáčková-Strouhal-Vargová 2004; Vlček 1996).

Publikovaných dokladů této nemoci pro pozdní středověk až starší novověk není zatím mnoho. Nedatované doklady syfilis z území České republiky pocházejí z kosterních pozůstatků z Mělníka (sbírka Hrdličkova muzea), z kostnice v Hrádku u Znojma (sbírka Katedry antropologie Komenského univerzity v Bratislavě), ze záchranného archeologického výzkumu kostnice ve Křtinách, dále z výzkumu pražského židovského hřbitova u Pinkasovy synagogy, ze znojemského náměstí Svobody a náměstí TGM v Břeclavi (Dofková-Drozdová 2012; Horáčková-Strouhal-Vargová 2004; Vlček 1996).

Do období, jež je vymezeno 16. až 19. stoletím, náleží hodnocené pohřby z prostoru chrámu sv. Petra a Pavla v Brně, Veselí nad Moravou - Sadové ulice, hřbitova u Nemocnice Milosrdných bratří v Brně a z bývalého hřbitova Malá Nová v dnešní brněnské Antonínské ulici (Vargová et al.

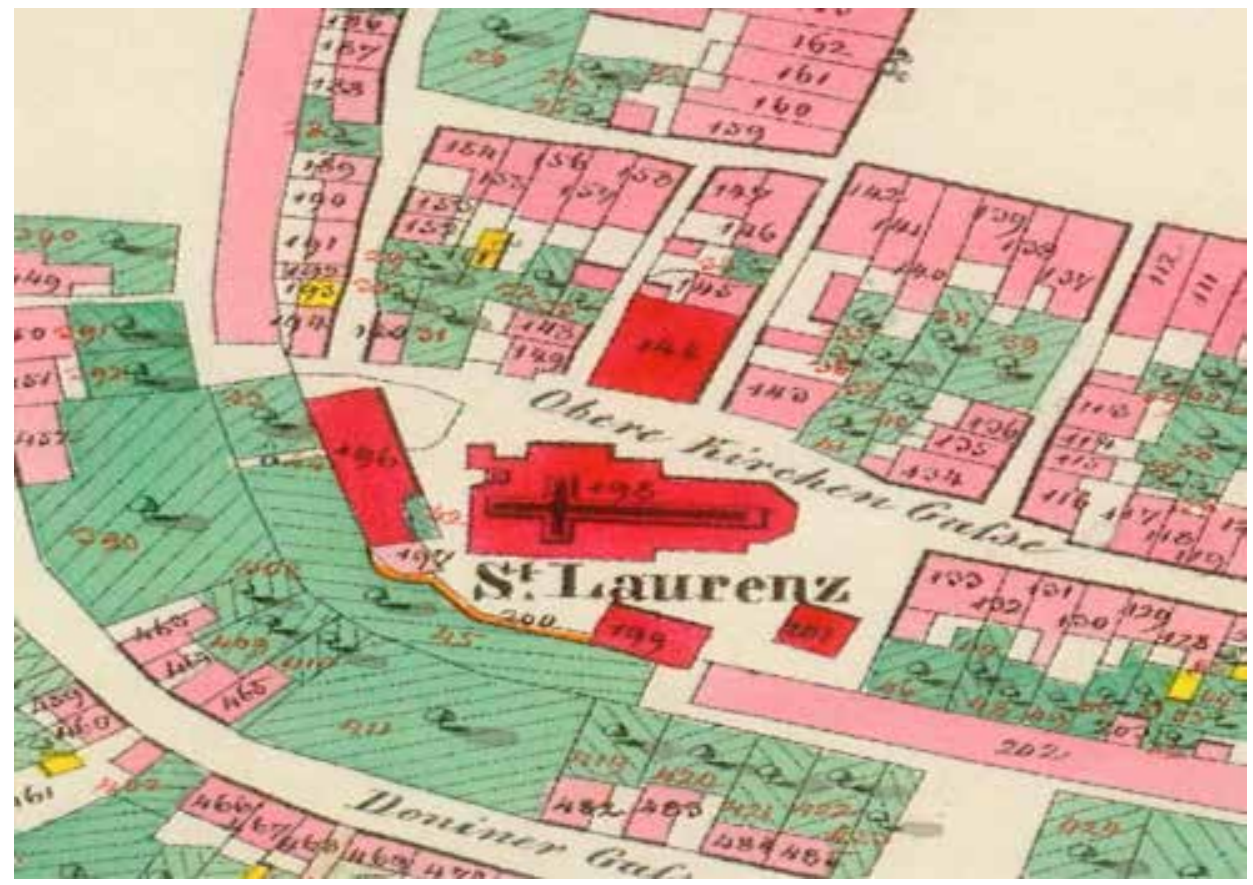

Obr. 14. Vysoké Mýto - dnešní Vaňorného náměstí. Otisk mapy stabilního katastru.

Abb. 14. Vysoké Mýto - heutiger Vaňorný-Platz. Abdruck der Stabilen Katasterkarte. 
2013; Vargová-Vymazalová-Horáčková 2019). Známky syfilitické infekce nesly rovněž kosterní pozůstatky pohřbů spojených s bitvou u Znojma z roku 1809 (Kovárník et al. 2006). Datované nálezy terciární syfilis přinesl také záchranný archeologický výzkum hřbitova kolem kostela sv. Benedikta a Norberta v Praze (dnešní náměstí Republiky) provedený v roce 1971. Díky nálezu muže z hrobu H4 ve Vysokém Mýtě, který je datován do staršího úseku 16. století, se s touto nemocí nyní setkáváme i ve východních Čechách.

\section{Závěr}

Záchranný archeologický výzkum vyvolaný rekonstrukcí Vaňorného náměstí ve Vysokém Mýtě, realizovaný v letech 2016-2017 přinesl i přes omezený rozsah některá nová zjištění.

Bylo zachyceno a $\mathrm{z}$ větší části v rámci možností i prozkoumáno 27 hrobů. Hroby v sondách 1 a 4 (a podle pozorování s největší pravděpodobností i v sondách 9 a 10) se nacházely ve vrstvách charakteru stavební planýrky datované nálezy do závěru 15 . až první poloviny 16 . století se staršími intruzemi. Vrstvy 104 a 106 dokládají pro okolí kostela sv. Vavřince rozsáhlé terénní úpravy související se stavebními aktivitami přibližně stejného časového úseku. Do těchto vrstev se podle výpovědi písemných a archeologických pramenů někdy ve druhé čtvrtině 16 . století následně intenzivně pohřbívalo, a to až do zrušení hřbitova kolem poloviny 16 . století. Na základě archeologických pramenů dokonce nemůžeme s jistotou vyloučit ani skutečnost, že se zde po jistou dobu ještě setrvačností pochovávalo paralelně s pohřbíváním kolem nově zřízeného kostela Nejsvětější Trojice.

Kosterní pozůstatky umožnily v rámci možností nahlédnout zdravotní stav obyvatel Vysokého Mýta ve vrcholném středověku a především v časném novověku. Z rámce standardních antropologických zjištění se zřetelně vymyká (bohužel neúplně prozkoumaný) hrob 24 se zlomeninou levé stehenní kosti způsobující svým špatným srůstem svému majiteli značné zdravotní potíže a zejména pak hrob $4 \mathrm{~s}$ doklady nákazy syfilis. Zjištěné spálené lidské kosti souvisí podle všeho $\mathrm{s}$ některou $\mathrm{z}$ požárových událostí v dějinách kostela vícekrát doložených.

Výzkum přinesl i poznatky o rozsahu vrcholně stř̌edověkého a časně novověkého hřbitova. Širší prostor před budovou gymnázia z roku 1882 se s jistotou nacházel mimo tento hřbitov, sonda 9 pak přinesla objev hranice hřbitova odděleného od okolního prostoru kamennou strukturou. Zda touto kamennou strukturou byla neobvykle masivní hřbitovní zed’ nebo již přímo městská hradba, neumožnil omezený rozsah výzkumu rozhodnout.

\section{Prameny}

CDB V/1: Codex diplomaticus et epistolaris regni Bohemiae. Tomus V. Fasciculus 1 (Šebánek, J.-Dušková, S., edd.). Pragae 1974.

CIM II: Codex iuris municipalis regni Bohemiae. Tomus II (Čelakovský, J., ed.). Praha 1895.

RBM II: Regesta diplomatica nec non epistolaria Bohemiae et Moraviae II. Praha 1882.

Staré letopisy české 1980: Ze starých letopisů českých (Kašpar, J.-Porák, J., edd.). Praha.

Zbraslavská kronika 1975: Zbraslavská kronika (Heřmanský, F.-Fiala, Z.-Mertlík, R., edd.). Praha.

\section{Literatura}

AUFDERHEIDE, A. C.-RODRÍGUEZ-MARTÍN, C., 2011: The Cambridge Encyclopedia of Human Paleopathology. Cambridge.

BROOKS, S. T.-SUCHEY, J. M., 1990: Skeletal Age Determination Based on pubis: A Comparison of the Acsadi-Nemeskeri and Suchey-Brooks Methods, Human Evolution 5, 227-238.

BRÜŽEK, J., 2002: A Method for Visual Determination of Sex, Using the Human Hip Bone, American Journal of Physical Anthropology 117/2, 157-168. https://doi.org/10.1002/ajpa.10012 
ČECHURA, M., 2010: Pohřební ritus ve středověku a novověku ve světle archeologického a antropologického výzkumu - Der Begräbnisritus im Mittelalter und der Neuzeit im Lichte der archäologischen und anthropologischen Forschung, AH 35, 111-120.

ČERNÝ, M.-KOMENDA, S., 1980: Sexual diagnosis by the measurements of humerus and femur, Sborník prací PedF UP Olomouc - Biologie 2, 147-167.

DOFKOVÁ, A.-DROZDOVÁ, E., 2012: Jedinci s podezřením na syfilis z náměstí Svobody ve Znojmě (Česká republika), Slovenská antropológia 15, 12-15.

DROZDOVÁ, E., 2004: Základy osteometrie. Panoráma biologické a sociokulturní antropologie. Brno.

FROLÍK, J., 2017: Pohřbívání ve vrcholném středověku a v novověku na Chrudimsku, Pardubicku a Kolínsku - Bestattungen im Hochmittelalter und in der Neuzeit in den Regionen Chrudim, Pardubice und Kolín, AH 42, 187-205.

FROLÍK, J.-MUSIL, J., 2016: Příspěvek k sociální identifikaci středověkých obyvatel Chrudimi na př́ikladu hřbitova u kostela Nanebevzetí Panny Marie - Ein Beitrag zur sozialen Identifikation der mittelalterlichen Einwohner von Chrudim am Beispiel des Friedhofs an der Mariä Himmelfahrtskirche, AH 41, 243-262.

FROLÍK, J.-SIGL, J., 1990: Soubor pozdně středověké keramiky z Chrudimi - Husovy ulice, Studies in Post-Medieval Archaeology 1, 269-284.

HIRT, M. et al., 2011: Tupá poranění v soudním lékařství. Praha.

HNÁT, J., 1934: Vysoké Mýto v boji za národní samostatnost. Několik historických kapitol ze staré i nové doby. Vysoké Mýto.

HORÁČKOVÁ, L.-STROUHAL, E.-VARGOVÁ, L., 2004: Základy paleopatologie. Panoráma biologické a sociokulturní antropologie. Brno.

HORÁČKOVÁ, L.-VARGOVÁ, L., 2009: Paleopatologie. Anatomie. In: Malina, J. et al., Antropologický slovník. Brno.

ISCAN, M. Y.-KEDICI, P. S., 2003: Sexual variation in bucco-lingual dimensions in Turkish dentition, Forensic Science International 137, 160-164. https://doi.org/10.1016/S0379-0738(03)00349-9

JIREČEK, H., 1884: Královské věnné město Vysoké Mýto. Obraz místopisný, dějepravný, životopisný i statistický. Vysoké Mýto.

- 1886-1900: Paměti města i kraje Vysokomýtského. Vysoké Mýto.

KAPLANOVÁ, K.-VÁCHA, Š., 2001: Chrám sv. Vavřince ve Vysokém Mýtě. Vysoké Mýto.

KOVÁRNÍK, J. et al., 2006: Kovárník, J.-Horáčková, L.-Vargová, L.-Mucha, L.-Vachunková, A., Hromadné hroby vojáků na Brněnské ulici z bitvy u Znojma v roce 1809 - Mass graves of soldiers on Brněnská Street from the Battle of Znojmo in 1809. In: Ve službách archeologie VII. Sborník věnovaný 85. narozeninám Doc. PhDr. Karla Valocha, DrSc. (Hašek, V.-Nekuda, R.-Ruttkay, M., edd.), 313-328. Brno.

KRSKOVÁ, D., 2001: Postavení měst v Království českém. Věnná města českých královen. Dvůr Králové nad Labem.

KUČA, K., 2011: Města a městečka v Čechách, na Moravě a ve Slezsku. V-Ž. Praha.

MANN, R. W.-MURPHY, S. P., 1990: Regional atlas of bone disease: a guide to pathologic and normal variation in the human skeleton. Springfield.

MURAIL, P. et al., 2005: DSP: A tool for probalistic sex diagnosis using worldwide variability in hip-bone measurements, Bulletins et mémoires de la Société d'Anthropologie de Paris 17, 167-176.

NECHVÁTAL, L., 2009: Původ syfilis: hypotézy ve světle nových molekulárních dat. Nepublikovaná bakalářská práce, ulož. na PřF MU, Brno.

NOVOTNÝ, V., 1985: Determination of sex from talus and calcaneus, Scripta medica 58, 437.

ROBERTS, Ch.-MANCHESTER, K., 2005: The Archaeology of Disease. Gloucestershire.

SCHAEFER, M. et al., 2009: Juvenile osteology. A laboratory and field manual. Amsterdam.

SCHMITT, A., 2005: A new method to assessadult age at death from the iliac sacro-pelvic surface, Bulletins et Mémoires de la Société d Anthropologie de Paris 17, 2-13.

SJØVOLD, T., 1990: Estimation of stature from long bones utilizing the line of organic correlation, Human Evolution 5, 431-447. https://doi.org/10.1007/BF02435593

SOMMER, P., 1977: Archeologický výzkum na náměstí a u kostela sv. Vavřince ve Vysokém Mýtě, o. Ústí nad Orlicí. In: Stř̌edověká archeologie a studium počátků měst, 120-121. Praha.

- 1981: Střenka ve tvaru sokolníka z Vysokého Mýta, Praehistorica VIII - Varia archaeologica 2, 315-318.

STLOUKAL, M., 1999: Antropologie: př́íručka pro studium kostry. Praha.

ŠEMBERA, A. V., 1845: Vysoké Mýto. Královské věnné město v Čechách. Olomouc.

ŠMEJDA, L., 1999: K hmotné kultuře Vysokého Mýta. In: Mediaevalia archaeologica 1 (Ježek, M.-Klápště, J., edd.), 169-192. Praha - Wrocław. 
VARGOVÁ, L.-VYMAZALOVÁ, K.-HORÁČKOVÁ, L., 2019: A brief history of syphilis in the Czech Lands, Archaeological and Anthropological Sciences 11, 521-530. https://doi.org/10.1007/s12520-017-0558-6

VARGOVÁ, L. et al., 2013: Vargová, L.-Horáčková, L.-Vymazalová, K.-Svoboda, J., Palaeopathological analysis of skeletons from the 16th and 17th centuries (Veselí nad Moravou, Czech Republic), Anthropologie LI, č. 3, 397-408.

VÍCH, D.-VOKOLEK, V., 1997: Nálezy získané do sbírek AO MVŠ v letech 1996-97, ZMHK 23, 3-27.

VLČEK, E., 1996: Syfilis v Čechách, paleopatologické doklady výskytu v druhé polovině 2. tisíciletí, Vesmír 75, 78-87.

VOTRUBEC, V., 1892: Kostel sv. Vavřince ve Vysokém Mýtě. Př́íspěvek k dějinám jeho stavby. Vysoké Mýto.

- 1897: Zvonice u kostela sv. Vavřince, Stráž na Vysokomýtsku I, č. 51, 6.

WALRATH, D. E.-TURNER, P.-BRŮŽEK, J., 2004: Reliability test of the Visual Assessment of Cranial Traits for Sex Determination, American Journal of Physical Anthropology 125, 132-137. https:/doi. org/10.1002/ajpa.10373

WIRTH, Z., 1902: Soupis památek historických a uměleckých v politickém okresu Vysokomýtském. Praha.

\section{Zusammenfassung}

\section{Die archäologische Grabung am Friedhof um die St. Laurentius-Pfarrkirche in Vysoké Mýto (Hohenfurt)}

Die Stadt Vysoké Mýto wurde in er ersten Hälfte der sechziger Jahre des 13. Jahrhunderts an einem höher gelegenen Ort oberhalb der Flussaue des Flusses Loučná gegründet. Während der Gründungszeit der Stadt entstand am südwestlichen Rand des Stadtareals bereits eine Pfarrkirche (Abb. 1:1). Die St. Laurentius-Kirche hat in den Jahren 1461, um das Jahr 1517 und am 6. August 1774 verschiedene Brandereignisse durchgemacht. Um die Kirche herum hat sich der städtische Friedhof erstreckt, der irgendwann Mitte des 16. Jahrhunderts an die vor den Stadtmauern neu gegründete (1543) Friedhofskirche der Hl. Dreifaltigkeit verlegt wurde (Abb. 1:2).

Die mit der Sanierung des heute die Kirche umgebenden Vaňorný-Platzes verbundene archäologische Rettungsgrabung ermöglichte es, einen detaillierteren Einblick in die Geschichte der Umgebung der St. Laurentius-Kirche zu erhalten. Im Jahr 2016 wurden die Sondierungsschnitte 1-8 gelegt (Abb. 2). Die Sondierungsschnitte 1-3 stellten die Startgruben für den Rohrvortrieb von Gasleitungsrohren dar, wobei Sondierschnitt 2 bis in das zerstörte Gelände reichte und Sondierschnitt 3 sich außerhalb des Friedhofsbereichs befand. In Sondierschnitt 1 wurden Gräber untersucht, wo wir auch die bis zum Untergrundsniveau reichenden darin enthaltenden Schichten und Bestattungen untersuchen (Abb. 3-6). Im Untergrund eingetiefte Grabgruben waren von der Grabung nicht mehr betroffen. Nach Grabungsende der Sondierschnitte 1-3 kam es an der Stelle des geplanten Kanalisationsschachtes zur Freilegung von Sondierschnitt 4, wobei anschließend lediglich das obere Gräberniveau untersucht wurde (Abb. 7-8). Danach haben wir mit maschinell gegrabenen Sondierschnitten den Umfang des Friedhofs überprüft (Sondierschnitte 5-8, Abb. 2). Die erhaltenen Angaben dienten dann dazu, die Projektpläne so abzuändern, dass die Störung der archäologischen Situationen bei der Sanierung des Marktplatzes im Laufe des darauffolgenden Jahres minimiert werden.

Im Jahr 2017 erfolgte die Rettungsgrabung dann bereits im Rahmen der durchgeführten Sanierung des Marktplatzes, wobei man aktuell verdeckte und sanierte Abschnitte als Sondierschnitte kennzeichnete. Hinsichtlich des Friedhofsumfangs erwiesen sich vor allem die Sondierschnitte 9, 10 und 11 (Abb. 2, 9, 10) als förderlich. Besonders Sondierschnitt 9, wo der Friedhof vom benachbarten Gelände von einer $1,9 \mathrm{~m}$ breiten Steinmauer abgetrennt wurde (Abb. 9), trug dazu bei, den Friedhofsumfang auszumachen.

Die entdeckten Gräber wurden in den Schichten 104 und 106 beigesetzt. Diese Schichten entstanden Ende des 15. bzw. eher in der ersten Hälfte des 16. Jahrhunderts im Zusammenhang mit den nach den Bränden der Jahre 1461 und 1517 an der Kirche erfolgten Renovierungsund Umbauarbeiten (Keramik siehe Abb. 13) und sind ein Beleg für die bei dieser Gelegenheit 
durchgeführten markanten Veränderungen des Geländes. In den dabei entstandenen Aufschüttungen wurden anschließend intensiv Bestattungen durchgeführt. Anhand eines Vergleichs der schriftlichen Nachrichten mit den archäologisch festgestellten Tatsachen dürften diese Gräber (vermutlich mit Ausnahme der untersten Gräber) in die erste Hälfte (bzw. eher ins zweite Viertel) des 16. Jahrhunderts datiert werden, wobei der neu gewonnene Raum in der relativ kurzen Zeit von höchstens ein bis zwei Jahrzehnten mit bestatteten Körpern gefüllt wurde. Allerdings können wir auch die Möglichkeit nicht ganz ausschließen, dass Bestattungen dort entgegen den schriftlichen Nachrichten noch eine zeitlang fortgesetzt wurden, und zwar parallel zu den Beisetzungen auf dem neu entstandenen Friedhof um die Hl. Dreifaltigkeitskirche. Die Bestattungen erfolgten ohne Grabbeigaben, nur bei Grab 1 fand sich am Schädel eine Stecknadel aus einer Kupferlegierung. Die Gräber wurden mit dem Kopf nach Westen bis Nordwesten und den Armen am Körper anliegend angelegt. Belege für einen Sarg oder für Bretter liegen uns lediglich bei Grab Nr. 15 vor, die übrigen wurden den festgestellten Tatsachen nach frei in der Erde bestattet.

Insgesamt konnten sechsundzwanzig Gräber in begrenztem Maße untersucht werden, von denen dreiundzwanzig einer anthropologischen Analyse unterzogen werden konnten. Dreizehn Skelette gehörten erwachsenen Männern, drei Skelette erwachsenen Frauen und fünf Skelette Kindern. Acht Personen waren älter als 40 Jahre, zwei Kinder im Alter von bis zu sechs Jahren und drei Kinder im Alter zwischen 6-14 Jahren. Die Körpergröße bewegte sich bei sieben Männern zwischen $166-175 \mathrm{~cm}$, bei einer Frau betrug sie $163 \mathrm{~cm}$. An pathologischen Veränderungen wurden neben den üblichen Behinderungen (Spondylosis deformans und Spondylarthrose einschließlich Schmorl-Knötchen, arthrotische Veränderungen des appendikulären Skeletts, Cribra orbitalia, Hypoplasie des Zahnschmelzes) eine ausgeheilte subtrochantäre dislozierte Fraktur des linken Oberschenkelknochens festgestellt, wobei die Verwundung wahrscheinlich durch einen Fall aus großer Höhe verursacht wurde (Grab 24, Abb. 11). Bei dem Mann aus Grab 4 gab es offensichtliche Spuren einer Syphiliserkrankung im dritten Stadium (Abb. 12). Die in Sondierschnitt 9 entdeckten verbrannten Knochen stellen sekundär umgebettete Gebeine von den vom Brand heimgesuchten Stellen dar.

PhDr. David Vích, Regionální muzeum ve Vysokém Mýtě, Šembreova 125, 56601 Vysoké Mýto, Česká republika,dvich@centrum.cz

Bc. Jana Šínová, Katedra historie Filozofické fakulty Univerzity Palackého v Olomouci, Na Hradě 5, 77900 Olomouc, Česká republika,jana.sinova@upol.cz

Bc. Tomáš Bek, Archeologický ústav AV ČR, Praha, v. v. i., Letenská 4, 11801 Praha 1, Česká republika, bek@arup.cas.cz 
